\title{
A 3D geological model of a structurally complex relationships of sedimentary Facies and Petrophysical Parameters for the late Miocene Mount Messenger Formation in the Kaimiro-Ngatoro field, Taranaki Basin, New Zealand
}

\author{
Surya Tejasvi Thota ${ }^{1} \cdot$ Md Aminul Islam $^{1} \cdot$ Mohamed Ragab Shalaby $^{1}$
}

Received: 5 June 2021 / Accepted: 30 October 2021 / Published online: 21 November 2021

(c) The Author(s) 2021

\begin{abstract}
The present study investigates the reservoir characteristics of the Mount Messenger Formation of Kaimiro-Ngatoro Field which was deposited in deep-water environment. A 3D seismic dataset, core data and well data from the Kaimiro-Ngatoro Field were utilized to identify lithofacies, sedimentary structures, stratigraphic units, depositional environments and to construct 3D geological models. Five different lithologies of sandstone, sandy siltstone, siltstone, claystone and mudstone are identified from core photographs, and also Bouma sequence divisions are also observed. Based on log character Mount Messenger Formation is divided into two stratigraphic units slope fans and basin floor fans; core analysis suggests that basin floor fans show better reservoir qualities compared to slope fan deposits. Seismic interpretation indicates 2 horizons and 11 faults, majority of faults have throw less than $10 \mathrm{~m}$, and most of the faults have high angle dips of $70-80^{\circ}$. The Kaimiro and Ngatoro Fields are separated by a major Inglewood fault. Variance attribute helped to interpret faults, and other seismic attributes such as root-mean-square amplitude, envelope and generalized spectral decomposition also helped to detect hydrocarbons. The lithofacies model was constructed by using sequential simulation indicator algorithm, and the petrophysical models were constructed using sequential Gaussian simulation algorithm. The petrophysical parameters determined from the models comprised of up to $\geq 25 \%$ porosity, permeability up to around $600 \mathrm{mD}$, hydrocarbon saturation up to $60 \%$, net to gross varies from 0 to $100 \%$, majority of shale volumes are around $15-20 \%$, the study interval mostly consists of macropores with some megapores and 4 hydraulic flow units. This study best characterizes the deep-water turbidite reservoir in New Zealand.
\end{abstract}

Keywords Slope fans $\cdot$ Basin floor fans $\cdot$ Stratigraphic units $\cdot$ Deep-water turbidites $\cdot$ Kaimiro-Ngatoro Field

\section{Introduction}

There has been increase in global energy demand due to huge growth in industries, economy and population; this made increasingly geoscientists and interpreters to involve in profound investigation and development of more complex fields and discovering new fields to meet the hydrocarbon requirements (Adelu et al. 2019). Lately, petroleum exploration in worldwide deep-water sedimentary basins achieved substantial success (King and Browne, 2002). Submarine

Surya Tejasvi Thota

surya.tejasvi134@gmail.com; 20h2063@ubd.edu.bn

1 Department of Geosciences, Faculty of Science, Universiti Brunei Darussalam, JalanTungku Link, Gadong 1410, Brunei Darussalam fans are most significant depositional environments in the deep-water settings, since most of the worldwide sedimentary basins consist of substantial petroleum reservoirs (Weimer and Link 1991). The sediments that deposited greater than $200 \mathrm{~m}$ bathymetry are considered as deep-water sediments (Browne et al. 2005) and deep -water settings are controlled by a variety of processes that frequently interconnect with one another at that period. The main controlling factors that affect the facies distribution of deep-water systems are accommodation space which depends on sea fall/ rise, sediment supply, climate, shelf sediment storage, transport mechanism, sea-floor gradient changes and basin morphology (Graham and Bachman 1983; Normark and Piper 1984; Bouma et al. 1985; Ghosh and Lowe 1993; Richards et al. 1998; Normark et al. 2002; Adeogba et al. 2005; Posamentier and Walker 2006; Flint et al. 2011; Cantalejo and 
Pickering 2014). The internal architecture and distribution of sands and clays in the submarine fans are highly composite. Generally, basin floor fans are accumulated when sands are carried into deep water through channels and canyons during initial and maximum low stand phases (King and Browne 2002), and are contemplated to spread as lobes with broad aerial scale, comprise of thick and continual sandstone deposits (King and Browne 2002), and also show blocky motifs in the gamma and SP logs (Mitchum et al. 1993). Slope fan deposits are formed as relative base level eventually starts to rise, sand contribution to the deep water decreases and is mostly restricted to fan units at the end of the slope (King and Browne 2002). Slope fan units are also determined as channel-levee complex or early low stand wedge of the low stand system tracts (Posamentier and Vail 1988; Posamentier et al. 1991); these are described by channels, rhythmic turbidites, scour and fill features (King and Browne, 2002), and show crescent-shaped motifs (Mitchum et al. 1993) or bell-shaped motifs (King et al. 1994) in the gamma and SP logs. Turbidites are sea-bottom deposits transferred from shallow to deep sea by turbidite currents; a typical turbidite is characterized by well-developed graded beds (Bouma et al. 1985; Shanmugam 2016), ripple marks and climbing ripple laminations. In general, the slumps and slides at the top of the slope areas might develop downslope into debris flows and then into turbidity currents, but not always turbidity currents are developed from debris flows; they might develop from sedimentary failures (Shanmugam 2016).

Even though our perception toward deep-water systems is gradually enhancing through the works done by several researchers on it worldwide, there is no existence of same deep-water systems since each system has distinct features. In this paper, the late Miocene deep-water turbidite "Mount Messenger Formation" within Kaimiro-Ngatoro Fields from Taranaki Basin has been studied and study area is located on Taranaki Peninsula, New Zealand. The highest hydrocarbon reserves in New Zealand are mostly from Taranaki Basin (Higgs et al. 2012) and the Mount Messenger Formation is one of them. The Mount Messenger Formation consists of submarine fans, formed due to rapid and continuous sedimentation in the northwest, where sediments are transported from the east and southeast hinterlands during tectonic uplift through central New Zealand (King et al. 1993; King and Thrasher 1996). Many research works were done on outcrops and very few works done with a combination of outcrops and subsurface of Mount Messenger Formation (King et al. 1994; King et al. 2001; Browne et al. 2002; Browne et al. 2005; Rotzein et al. 2014; Masalimova et al. 2016; Silver et al. 2021). Many researchers used several techniques on distinct parts of reservoir characteristics of most promising hydrocarbon formations in New Zealand and mostly focused on the Taranaki Basin (Griffin et al. 2015; Prieto and Archer 2015; Qadri et al. 2016, 2017, 2019; Haque et al. 2016; Dong et al. 2018). Mainly, basin scale studies were conducted by King and Thrasher (1996); Higgs et al. (2012); Ilg et al. (2012); Roncaglia et al. (2013); Sarma et al. (2014); Qadri et al. (2016); Infante-Paez and Marfurt (2017); AlHakeem (2018); Jumat et al. (2018); Franzel and Back (2019); Kutovaya et al. (2019), while very less researchers have studied reservoir characterization using a 3D modeling on field scale (Roncaglia et al. 2010; Alotaby 2015; Alotaibi 2015; Haque et al. 2016; Higgs et al. 2017; Qadri et al. 2017, 2019; Mennan 2017 and Islam et al. 2020). So far, to the best of our knowledge, no field-scale 3D structural and property modeling was carried out considering Mount Messenger Formation within Kaimiro-Ngatoro Field.

The objectives of this study are to identify structural features by using seismic interpretation, seismic attributes, surface maps and 3D structural modeling, to analyze the sedimentological features and lithological distribution by using core photographs, to identify the stratigraphic units and depositional environments based on gamma and SP logs, to construct 3D property models including facies and petrophysical properties considering porosity, permeability, water saturation, hydrocarbon saturation, volume of shale, net to gross, reservoir quality index, flow zone indicator and to analyze the spatial distribution of the Mount Messenger Formation within the Kaimiro-Ngatoro Fields.

\section{Geological background and tectonic setting}

Taranaki Basin is located along the western coast of the North Island of New Zealand. This basin has a large area of approximately $100,000 \mathrm{~km}^{2}$ and is mostly offshore (Fig. 1). A lot of research work focused on the formation and development of Taranaki Basin (Pilaar and Wakefield 1978; Thrasher 1992; King and Thrasher 1996; Palmer and Geoff 1988; Palmer 1985; Stagpoole and Nicol 2008; Uruski 2008).

The Taranaki Basin is made up of two major structural features: The Eastern Mobile Belt, also known as the Taranaki graben, and the Western Stable Platform (Pilaar and Wakefield 1978; Palmer and Geoff 1988; King et al. 1991). The two major structural blocks are set apart from each other by Cape Egmont Fault Zone comprising a set of steep, subparallel, normal to reverse faults that are trending in NS to NE-SW directions (Pilaar and Wakefield 1978). In the Eastern Mobile Belt, the Taranaki Basin has complex tectonic and sedimentary history that encompasses superimposed sub-basins, normal, reverse and overthrust faulting and areas of uplift. The Taranaki Graben, an 80-kmwide faulted depression, occupies the eastern part of the basin. The Graben area is highly structured and contains a sedimentary sequence in places up to $11,000 \mathrm{~m}$ thick (King and Thrasher 1996). On the other hand, the Western Stable 


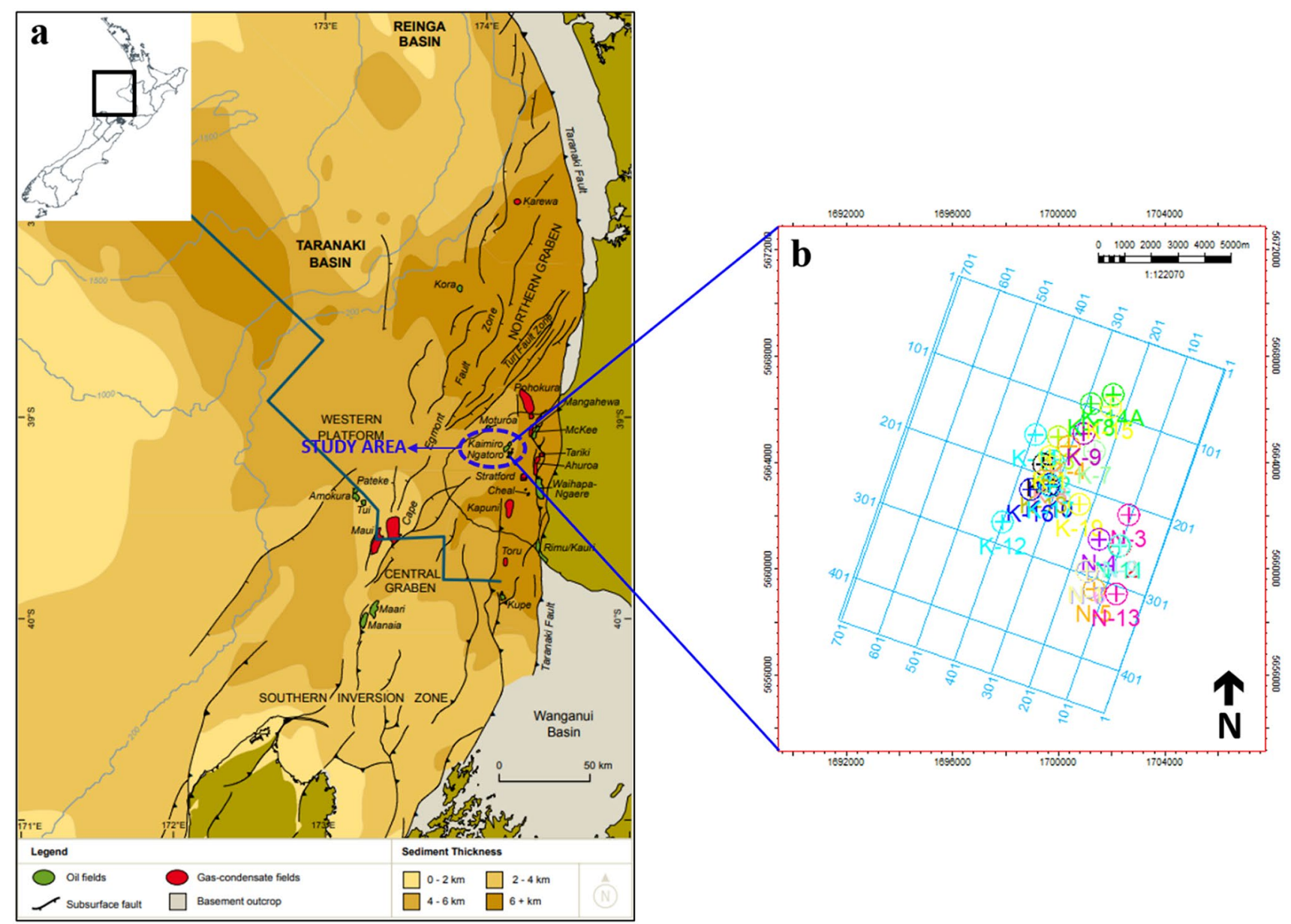

Fig. 1 aThe location of the Taranaki Basin is shown on the top left map, and various oil and gas condensate fields are displayed. The blue highlighted Kaimiro-Ngatoro Field indicates the study area

Platform, a 100-km-wide shelf, underlies deeper water in the mid and outer parts of the continental shelf in the west. This area is characterized by a broad, simple structure and a maximum of about 5,000 m of sedimentary section (Palmer 1985).

The Taranaki Basin was formed by continental rifting during the late Cretaceous, which separated New Zealand from Australia and formed Tasman Sea (Thrasher 1992; Kroeger et al. 2013; Baur et al. 2014). A number of halfgrabens were formed at that time and were active until the end of the Paleocene. These were rapidly filled with thick clastic sequences. The first sediments deposited in the late Cretaceous were sandstone, shale and coal of the Rakopi Formation, then followed by North Cape Formation, where shallow marine and coastal units were deposited as a result of flooding (King and Thrasher 1996; Kroeger et al. 2013) (Fig. 2).

Following the cessation of rifting in the Paleocene, the region became a passive continental margin (King and (modified after New Zealand Petroleum Basins 2014). b Seismic lines and wells of Kaimiro and Ngatoro Field

Thrasher 1996; Strogen et al. 2014). Gradual subsidence continued through the Eocene under the effects of sag relating to thermal decay. Non-marine, paralic and marine sediments were deposited over the entire basin. The region was open to full marine conditions to the northwest. Paleocene is comprised of primarily sand-dominated Farewell Formation and offshore mudstones of the Turi Formation (King and Thrasher 1996). Eocene strata comprise the sand-rich Kaimiro Formation, following that regionally coal-rich Mangahewa Formation, after this shoreline sandstones of the Mckee Formation, and shelfal mudstones of the Turi Formation were gradually deposited across the top of the Mangahewa Formation and in the northwestern part of the basin at this time (King and Thrasher 1996) (Fig. 2). Paleocene-Eocene consists of most important and efficient rocks in the Taranaki Basin. Coaly facies are the source rock for some hydrocarbons in the Taranaki, and associated sandstones are the main reservoir rocks in the basin (Higgs et al. 
Fig. 2 Generalized stratigraphy of the Taranaki Basin, New Zealand. Modified after King and Thrasher (1996)

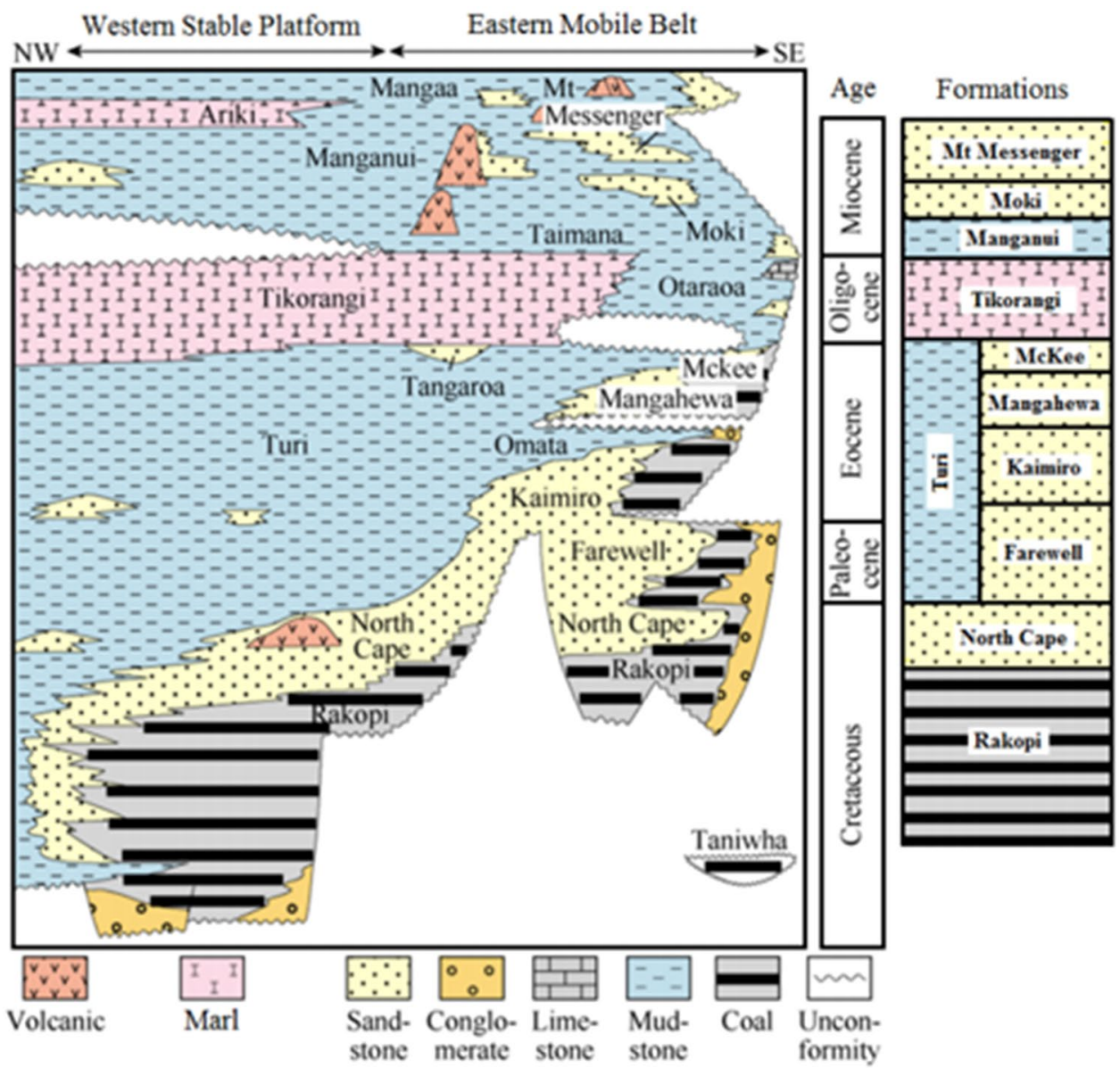

2012), and the overlying mudstones of the Turi Formation act as regional seal to the reservoirs.

The onset of compressional tectonic activity in New Zealand in the Oligocene resulted in rapid subsidence of a foredeep in the eastern part of the Taranaki Basin (Holt et al. 1994; King and Thrasher 1996). Simultaneously, during the late Eocene and Oligocene, the Taranaki Fault complex became progressively active along the eastern margin of the Taranaki Basin (Nicol et al. 2004). A deep marine trough formed along the downthrown western side of the Taranaki Fault, where it is filled by carbonates and sandy turbidites. These comprise of marly deposits of the Otaraoa Formation, inter-bedded turbidite sandstones of the Tariki Sandstone Member which initiated from the faultcontrolled margin to the east and southeast (Higgs et al. 2004), Matapo Sandstone Member, Tikorangi Limestone reservoir unit (Fig. 2).

Compressional tectonic activity was followed in the early Miocene by a major regressive phase initiated by compressional uplift to the east of the Taranaki Fault (King and Thrasher 1996; Vonk et al. 2008). This phase lasted until the late Miocene. The shelf margin during this stage was tectonically controlled and very steep. Miocene strata comprise of marine, regressive, clastic-dominated sequence. These include shelf, slope and basin floor mudstones/siltstones of Manganui Formation, sandstone deposits of Mount Messenger and Moki Formations, slope siltstones of Urenui Formation, deep-water volcaniclastics of the Mohakatino Formation and basin floor marls of the Ariki Formation (Fig. 2). Late Miocene Mount Messenger Formation is the reservoir within the onshore Kaimiro and Ngatoro Fields (King et al. 1993; King and Thrasher 1996).

Compressional activity waned toward the end of the Miocene, but was replaced by an episode of extensional-wrench associated with back-arc spreading in the Pleistocene period (King et al. 1993; King and Thrasher 1996). This resulted in renewed subsidence in the Taranaki Graben and continued rapid clastic sedimentation in deep-water conditions. Pliocene-Pleistocene succession consists of Matemateaonga, Tangahoe, Manga and Giant Forests Formations (King and Thrasher 1996) (Fig. 2). The western boundary fault of the Taranaki Graben, the Cape Egmont Fault Zone, was formed at this time. The Western Platform to the west, however, was largely unaffected by both this extensional-wrench episode and the preceding compressional phase. Passive sag continued virtually uninterrupted on the Western Platform 
from the Eocene through the Pliocene (Pilaar and Wakefield 1978).

The Kaimiro-Ngatoro structure lies on an ancient north northeast - south southwest fold trend which formed the Kupe, Kapuni, Stratford, Inglewood, Ngatoro and Kaimiro structures. The Kaimiro structure is a broad anticline with four-way dip closure. The Kaimiro-Ngatoro area is bisected by the Inglewood Fault, a major fault which can be identified and mapped at surface. The surface trace shows changes in Inglewood Fault trend, ENE-WSW trend to a more N-S trend immediately to the northeast of the Kaimiro Field. The structure lies on an Eocene structural trend and was probably initiated at that time, though the main phase of movement occurred during the Miocene as a result of widespread compressional tectonics. This phase of structuring was followed by an extensional relaxation and normal faulting. The structural trend lies within the Taranaki Graben, which contains some $6,000 \mathrm{~m}$ plus of late Cretaceous to Tertiary sedimentary rocks. The Graben is bounded on the east by the Taranaki Fault. Movement on this fault has upthrown the Patea-Tongaporutu High to the east. The west side of the Graben is marked by the Cape Egmont Fault Zone which separates the Graben from the less deformed Western Platform. The information about Kaimiro-Ngatoro structure mentioned here is from well completion reports.

\section{An overview of stratigraphy and sedimentology of the Mount Messenger Formation}

The formation was first described from a thick succession exposed in cliffs along the north Taranaki coast (Schofield 1959). Mount Messenger Formation of Wai-iti Group, which formed as a result of high rates of sediment supply, caused by tectonism during the Neogene period. The Mount Messenger Formation comprises of approximately 600-m-thick (King et al. 1994) interbedded sandstone, siltstone and mudstone in varying proportions. Sandstone content is always noteworthy, but is not necessarily the dominant lithology. The Mount Messenger Formation was deposited in lower to mid-bathyal water depths and best developed in the northeastern part of Taranaki Basin during late Miocene (King and Thrasher 1996). The Mount Messenger Formation sandstones are usually fine- to very fine-grained and vary in thickness from individual beds of less than $1 \mathrm{~m}$ to amalgamated bodies 10-40 m thick. The Mount Messenger reservoir sandstones were observed in various onshore and offshore Taranaki wells (King and Thrasher 1996).

The Mount Messenger Formation deposition can be divided into two stratigraphic units, namely Lower Mount Messenger Formation and Upper Mount Messenger
Formation (Browne et al. 2002). The Lower Mount Messenger Formation comprises of basin floor fans, thick-bedded and thin-bedded sandstones, in which thick sandstones are massive and convolute bedded, and interbedded with minor mudstones, while thin bedded sandstone consists of horizontal and ripple laminated sandstone with higher mudstone percentage than thick-bedded sandstone (King et al. 1994). The Upper Mount Messenger Formation comprises of slope fan deposits; these are channel-levee complexes specified by thin-bedded sandstone and siltstone with climbing ripplelaminated sedimentary structures (King et al. 1994). Net/ gross ratios vary greatly in the Mount Messenger Formation, reflecting local variability of the submarine fan complexes. The rocks in this formation constitute a diversity of submarine gravity flow sediments, as well as turbidites, debris flow sediments and hemipelagic mudstone (Crundwell 2004a, b).

\section{Data and methodology}

\section{Materials}

The 3D seismic data, well data and core data (includes core photographs and routine core analysis) were used in this study acquired from New Zealand Petroleum and Minerals.

\section{Seismic data}

The seismic data are in SEG-Y format and covers 63.585 square kilometers (Kaimiro Field covering $22.131 \mathrm{~km}^{2}$ and Ngatoro Field $41.454 \mathrm{~km}^{2}$ ). The Kaimiro-Ngatoro Field consists of 708 inlines and 457 crosslines. Table 1 shows the Kaimiro-Ngatoro-3D seismic SEGY file header, and Table 2 shows data acquisition parameters.

\section{Well data}

Wells of Kaimiro K-1, 2, 3, 4, 5, 6, 7, 8, 9, 10, 11, 12, 13, 14A, 15, 16, 17, 18 and 19 and wells of Ngatoro N-1, 2, 3, 4, 5, 6,7, 9, 11 and 13 (total 29 wells) were used in this study. The dataset includes well logs, formation tops, deviation survey and checkshots. Well coordinates, formation top and bottom can be found in Table 3. Different well logs (caliper, gamma ray, density, neutron, resistivity, spontaneous potential, sonic, etc.,) available for each well are shown in Table 4.

\section{Core data}

Core photographs and routine core analysis were used in this study. Core photographs are available for K-2, 15, 16, $18, \mathrm{~N}-2,3,4,7,9$ and 11 wells (Table 3). Core analysis is available for K-2, 15, 16, 18, N- 2, 3, 4, 5, 7, 9 and 11 wells.

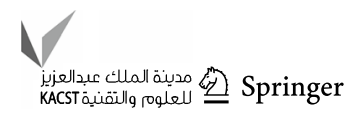


Table 1 SEG-Y file text header of the Kaimiro-Ngatoro_3D seismic data

\begin{tabular}{ll}
\hline Area & $\begin{array}{l}\text { Taranaki Basin-KAIMIRO-NGATORO_3D } \\
\text { Migration }\end{array}$ \\
\hline Survey & 3D-KAIMIRO-NGATORO \\
Inline & $1-708$ \\
Xline & $1-457$ \\
CDP & $1001-708,457$ \\
Sample rate & 4000 \\
Record length & 4600 \\
Class & 3D Seismic \\
Points used for & Inline 1 Xline 1; 1706251E 5667490 N \\
Survey definition & Inline 1 Xline 457; 1701719E 5654585 N \\
& Inline 708 Xline 457; 1691715E 5658098 N \\
Tracer header byte locations \\
Inline & BYTES 13-16 \\
Xline & BYTES 17-20 \\
Projection & NZTM \\
Datum & NZGD2000 \\
\hline
\end{tabular}

\section{Methods}

\section{Seismic interpretation}

Firstly, 3D seismic data and well data were imported to the Petrel software (Petrel 2019 version was used). In this study, seismic interpretation was carried out for the Mount Messenger Reservoir Formation in Kaimiro-Ngatoro Field. This was executed by using 708 inlines and 457 crosslines within the 3D seismic cube (Fig. 1). Well to seismic tie and checkshot data helped to identify and interpret the horizon tops on reflections of seismic data. This step is very necessary since well data are in depth domain and seismic data are in time domain. Before starting the interpretation of faults and horizons, trace automatic gain control (AGC) was applied to the seismic data to improve the seismic resolution which later helps to pick up the seismic horizons with greater confidence. Top Mount Messenger, bottom Mount Messenger horizons and eleven faults were interpreted using the seismic data. Variance seismic attribute was generated to support the interpreted faults, while RMS (root-mean-square) amplitude, envelope, and generalized spectral decomposition seismic attributes were generated to check the presence of the hydrocarbons. The velocity modeling was carried out to convert the interpreted faults and horizons into depth domain. Figure 3 shows the workflow of developing structural and property models for this study.

\section{D Structural modeling}

The interpreted faults and horizons in depth domain were used as input data for generating 3D structural modeling. These algorithms were corroborated with few researchers

Table 2 Data acquisition parameters for the Kaimiro-Ngatoro Field

\begin{tabular}{|c|c|}
\hline \multicolumn{2}{|l|}{ Source } \\
\hline Source & Single holes \\
\hline Charge size per hole & 2 kg Powergel \\
\hline Charge depth & $10 \mathrm{~m}$ \\
\hline \multicolumn{2}{|l|}{ Receivers } \\
\hline Geophone pattern & $\begin{array}{l}12 \text { sensor SM4 geophones laid in a } 2442 \text { weighted pattern, with } 2.0 \mathrm{~m} \text { between adjacent ele- } \\
\text { ments, centered on the station peg }\end{array}$ \\
\hline \multicolumn{2}{|l|}{ Geometry } \\
\hline Receiver line interval & $240 \mathrm{~m}$ \\
\hline Receiver station interval & $30 \mathrm{~m}$ \\
\hline Shot line interval & $240 \mathrm{~m}$, orthogonal to receiver lines, crossing at mid station \\
\hline Shotpoint interval & $60 \mathrm{~m}$ between each of 4 in a 'brick' between receiver lines \\
\hline Spread & 124 channels per receiver line, 8 receiver lines per record. 4 lines either side of shotpoint 'brick' \\
\hline Fold of cover & 31 maximum. Midpoints clustered in center of bin \\
\hline Bin size & $15 \mathrm{~m}$ (in line of geophones) $\times 30 \mathrm{~m}$ (in line of shots) \\
\hline \multicolumn{2}{|l|}{ Instruments } \\
\hline No. of channels & $992+4$ auxiliaries \\
\hline Sample rate & $2 \mathrm{~ms}$ \\
\hline Record length & $6 s$ \\
\hline Format & SEG-D demultiplexed \\
\hline Record Filters & $\begin{array}{l}\text { Low cut } 8.7 \mathrm{~Hz}, 12 \mathrm{~dB} / \text { octave } \\
\text { High cut } 180 \mathrm{~Hz}, 72 \mathrm{~dB} / \text { octave }\end{array}$ \\
\hline
\end{tabular}


Table 3 Well and core data parameters

\begin{tabular}{|c|c|c|c|c|c|c|c|}
\hline \multirow[t]{2}{*}{ Well name } & \multirow[t]{2}{*}{$\mathrm{X}$-coordinate } & \multirow[t]{2}{*}{ Y-coordinate } & \multicolumn{2}{|c|}{$\begin{array}{l}\text { True vertical depth sub- } \\
\text { sea (TVDSS, meters) }\end{array}$} & \multicolumn{2}{|c|}{$\begin{array}{l}\text { Measured depth (MD, } \\
\text { meters) }\end{array}$} & \multirow{2}{*}{$\begin{array}{l}\text { Core/Cuttings } \\
\text { photograph (meters } \\
\text { in MD) }\end{array}$} \\
\hline & & & Top & Bottom & Top & Bottom & \\
\hline Kaimiro-1 (K-1) & $1,699,665.632$ & $5,664,247.113$ & 994.5 & 1513.5 & 1260 & 1779 & NA \\
\hline Kaimiro-2 (K-2) & $1,699,705.902$ & $5,664,332.917$ & 985.5 & 1512 & 1249 & 1791 & $1359-1379$ \\
\hline Kaimiro-3 (K-3) & $1,699,971.217$ & $5,664,999.675$ & 1002 & 1522 & 1250 & 1770 & NA \\
\hline Kaimiro-4 (K-4) & $1,700,382.421$ & $5,664,633.169$ & 813 & 1493 & 1060 & 1740 & NA \\
\hline Kaimiro-5 (K-5) & $1,699,421.483$ & $5,663,963.634$ & 835 & 1519 & 1224 & 1788 & NA \\
\hline Kaimiro-6 (K-6) & $1,700,180.627$ & $5,663,989.732$ & 813.6 & 1521.3 & 1076 & 1890 & NA \\
\hline Kaimiro-7 (K-7) & $1,701,006.929$ & $5,664,142.088$ & 955.2 & 1792.2 & 1207 & 2130 & NA \\
\hline Kaimiro-8 (K-8) & $1,699,673.187$ & $5,663,205.799$ & 859 & 1373.3 & 1173 & $1772(\mathrm{TD})$ & NA \\
\hline Kaimiro-9 (K-9) & $1,700,382.818$ & $5,664,638.168$ & 921.4 & 1220.4 & 1348 & 1753(TD) & NA \\
\hline Kaimiro-10 (K-10) & $1,699,626.997$ & $5,663,203.366$ & 926 & 1282 & 1202 & 1557(TD) & NA \\
\hline Kaimiro-11 (K-11) & $1,699,268.625$ & $5,664,726.639$ & 944.6 & 1410.9 & 1203 & 1723(TD) & NA \\
\hline Kaimiro-12 (K-12) & $1,697,447.007$ & $5,661,501.89$ & 910.1 & 1349.5 & 1335 & 1835(TD) & NA \\
\hline Kaimiro-13 (K-13) & $1,699,633.501$ & $5,663,196.872$ & 834 & 1263.9 & 1110 & 1604(TD) & NA \\
\hline Kaimiro-14A (K-14A) & $1,701,890.865$ & $5,667,334.226$ & 797 & 1363.7 & 1067 & 1843(TD) & NA \\
\hline Kaimiro-15 (K-15) & $1,701,202.312$ & $5,666,218.502$ & 799.6 & 1433.3 & 1115 & 1860 & $1485-1492$ \\
\hline Kaimiro-16 (K-16) & $1,699,626.893$ & $5,663,208.665$ & 823 & 1237.7 & 1215 & 1717(TD) & $1585-1616.7$ \\
\hline Kaimiro-17 (K-17) & $1,699,671.119$ & $5,663,163.005$ & 827.9 & 1214.7 & 1168 & 1633 & NA \\
\hline Kaimiro-18 (K-18) & $1,701,226.703$ & $5,666,237.937$ & 840 & 1158.1 & 1150 & $1520(\mathrm{TD})$ & $1441-1472.8$ \\
\hline Kaimiro-19 (K-19) & $1,699,632.214$ & $5,663,178.674$ & 912.4 & 1183.5 & 1542 & 2178 & NA \\
\hline Ngatoro-1 (N-1) & $1,701,050.283$ & $5,659,969.657$ & 891.6 & 1499.6 & 1219 & 1827 & NA \\
\hline Ngatoro-2 (N-2) & $1,702,323.767$ & $5,660,921.287$ & 1024.06 & 1392.06 & 1319 & 1687 & $\begin{array}{l}1453-1459.7 \\
1572.8-1604.8\end{array}$ \\
\hline Ngatoro-3 (N-3) & $1,702,637.094$ & $5,662,064.329$ & 1026.06 & 1419.06 & 1294 & 1687 & $\begin{array}{l}1417-1432 \\
1435-1452.4 \\
1580-1598.7\end{array}$ \\
\hline Ngatoro-4 (N-4) & $1,701,524.542$ & $5,661,145.829$ & 1045.8 & 1522.3 & 1343.7 & 1820 & $\begin{array}{l}1438-1464.5 \\
1578-1591.8\end{array}$ \\
\hline Ngatoro-5 (N-5) & $1,701,335.714$ & $5,659,263.758$ & 983.4 & 1484.4 & 1319 & 1820 & NA \\
\hline Ngatoro-6 (N-6) & $1,701,088.578$ & $5,659,938.869$ & 1117 & 1602 & 1445 & 1930(TD) & NA \\
\hline Ngatoro-7 (N-7) & $1,701,084.676$ & $5,659,942.366$ & 968 & 1552 & 1295 & 1879(TD) & $1727-1782$ \\
\hline Ngatoro-9 (N-9) & $1,702,316.363$ & $5,660,927.981$ & 1015.1 & 1462.8 & 1463.2 & 2003.9(TD) & 1767-1817.2 \\
\hline Ngatoro-11 (N-11) & $1,702,275.394$ & $5,660,894.957$ & 1031.9 & 1563.4 & 1510.2 & 2061.4(TD) & $1701-1792$ \\
\hline Ngatoro-13 (N-13) & $1,702,168.692$ & $5,659,093.175$ & 682.5 & 1229.4 & 1068 & 1898 & NA \\
\hline
\end{tabular}

*TD—Total depth, NA—Not available

for instance, Haque et al. (2016) and Islam et al. (2020) who included VBM algorithm in their studies. Traditional modeling methods in general require oversimplification of geological settings; however, grid-generated VBM captures realistic reservoir architecture. These can be easily transferred into dynamic realm providing a better understanding of the reservoir for the future field management and development. The main steps involved in this process are structural framework, fault modeling, horizon modeling and zones layering; in this study, during layering process 200 layers have been selected to incorporate even very small details into the model, since Mount Messenger Formation consists of very thin beds.

\section{Property modeling}

The depositional facies were interpreted by predominantly considering well log responses including core photographs. Five lithofacies were identified within the Mount Messenger Formation based on the core description of the Ngatoro-2 well, and its gamma ray response helped to identify the lithology in remaining wells. The generated 3D grid in structural modeling was used to construct facies and petrophysical modeling. The interpreted lithology log was upscaled, and then, sequential indicator simulation (SIS) algorithm was applied to construct facies modeling. Some authors used 
Table 4 Log information of each well

\begin{tabular}{|c|c|}
\hline Well name & Log information \\
\hline Kaimiro-1 (K-1) & BS; CALI; DENS; DRHO; DTC; GR; NEUT; RESD; RESS; SP; \\
\hline Kaimiro-2 (K-2) & BS; CALI; DENS; DRHO; GR; NEUT; PEF; TEMP; TENS \\
\hline Kaimiro-3 (K-3) & BS; CALI; DENS; DRHO; DTC; GR; NEUT; PEF; RESD; RESS; SP; TEMP; TENS \\
\hline Kaimiro-4 (K-4) & BS; CALI; DENS; DRHO; DTC; GR; NEUT; RESD; SP; TEMP; TENS \\
\hline Kaimiro-5 (K-5) & BS; CALI; DENS; DRHO; DTC; GR; NEUT; PEF; RESD; RESS; SP; TEMP; TENS \\
\hline Kaimiro-6 (K-6) & BS; CALI; DENS; DRHO; DTC; GR; NEUT; RESD; RESM; SP; TEMP \\
\hline Kaimiro-7 (K-7) & BS; CALI; DENS; DRHO; DTC; GR; NEUT; RESD; RESM; SP; TEMP \\
\hline Kaimiro-8 (K-8) & BS; CALI; DENS; DRHO; DTC; GR; NEUT; RESD; RESM; SP; TEMP; TENS \\
\hline Kaimiro-9 (K-9) & BS; CALI; DTC; GR; RESD; RESM; SP; TEMP; TENS \\
\hline Kaimiro-10 (K-10) & BS; CALI; DENS; DRHO; DTC; GR; NEUT; RESD; RESM; SP; TEMP; TENS \\
\hline Kaimiro-11 (K-11) & BS; CALI; DENS; DRHO; DTC; GR; NEUT; RESD; RESM; SP; TEMP; TENS \\
\hline Kaimiro-12 (K-12) & BS; CALI; DENS; DRHO; DTC; GR; NEUT; RESD; RESS; SP; TEMP; TENS \\
\hline Kaimiro-13 (K-13) & BS; CALI; DENS; DRHO; DTC; GR; NEUT; RESD; RESS; SP; TEMP; TENS \\
\hline Kaimiro-14A (K-14A) & BS; CALI; DENS; DRHO; DTC; GR; RESD; RESS; SP; TEMP; TENS \\
\hline Kaimiro-15 (K-15) & BS; CALI; DENS; DRHO; DTC; GR; NEUT; RESD; RESS; SP; TEMP; TENS \\
\hline Kaimiro-16 (K-16) & NA \\
\hline Kaimiro-17 (K-17) & NA \\
\hline Kaimiro-18 (K-18) & BS; CALI; DENS; DTC; GR; NEUT; PEF; RESD; RESM; RESS; SP \\
\hline Kaimiro-19 (K-19) & NA \\
\hline Ngatoro-1 (N-1) & BS; CALI; DENS; DRHO; DTC; GR; NEUT; RESD; RESS; SP; TEMP; TENS \\
\hline Ngatoro-2 (N-2) & BS; CALI; DENS; DRHO; DTC; GR; NEUT; PEF; RESD; RESS; SP; TEMP; TENS \\
\hline Ngatoro-3 (N-3) & BS; CALI; DENS; DRHO; DTC; GR; NEUT; PEF; RESD; RESS; SP; TEMP; TENS \\
\hline Ngatoro-4 (N-4) & BS; CALI; DRHO; DTC; GR; NEUT; PEF; RESD; RESS; SP; TEMP; TENS \\
\hline Ngatoro-5 (N-5) & NA \\
\hline Ngatoro-6 (N-6) & BS; CALI; DENS; DTC; GR; NEUT; PEF; RESD; RESS; SP \\
\hline Ngatoro-7 (N-7) & BS; CALI; DENS; DTC; GR; NEUT; PEF; RESD; RESS; SP \\
\hline Ngatoro-9 (N-9) & BS; CALI; DENS; DRHO; DTC; GR; NEUT; PEF; RESD; RESS; SP; TEMP; TENS \\
\hline Ngatoro-11 (N-11) & BS; CALI; DENS; DRHO; DTC; GR; NEUT; PEF; RESD; RESS; SP; TENS \\
\hline Ngatoro-13 (N-13) & BS; CALI; DENS; DRHO; DTC; GR; NEUT; PEF; RESD; RESS; SP; TENS; DTS; \\
\hline
\end{tabular}

*BS-Bit size; CALI-Caliper; DENS-Density; DRHO-Bulk density correction; DTC-Delta-T Compressional; DTS-Delta-T Shear; GR-Gamma Ray; NEUT-Neutron; PEF-Photoelectric factor; RESD-Deep Resistivity; RESM-Medium Resistivity; RESS- Shallow Resistivity; SP-Spontaneous Potential; TEMP-Cartridge Temperature; TENS- Cable Tension; NA- Not available

computer to analyze the seismic facies (Hashemi 2012; Hadiloo et al. 2017).

The petrophysical modeling was also developed using 3D model grid of structural modeling, same like facies modeling. Interactive Petrophysics (IP) software was used to perform well log-based petrophysical analysis for Mount Messenger Formation. The volume of the shale was estimated using equation of Dresser Atlas (1979) for Tertiary rocks (Eq. 1).

$V_{s h}=0.083 \times\left(2^{3.7 I_{s h}}-1\right)$

The total $(\Phi \mathrm{t})$ and effective $(\Phi \mathrm{e})$ porosities of the Mount Messenger Formation were calculated using neutron-density combination logs. According to Schlumberger (1991), the porosity can be estimated from the density log using Eq. 2.
$\Phi_{D}=\frac{\rho_{m a}-\rho_{b}}{\rho_{m a}-\rho_{f}}$

where $\Phi D$ is the porosity derived from density log, $\rho$ ma $(2.65 \mathrm{gm} / \mathrm{cc})$ is the matrix density, $\rho b$ is the bulk density, and $\rho f(1.1 \mathrm{gm} / \mathrm{cc})$ is the density of the saturation fluid. Porosity can also be estimated from neutron log using Eq. 3.

$\Phi_{N}=\Phi$

where $\Phi$ is the total porosity and $\Phi N$ is the apparent neutron porosity. The total porosity of the formation is then calculated from the following equation:

$\Phi t=\sqrt{ }\left(\Phi_{N}^{2}+\Phi_{D}^{2}\right)$ 


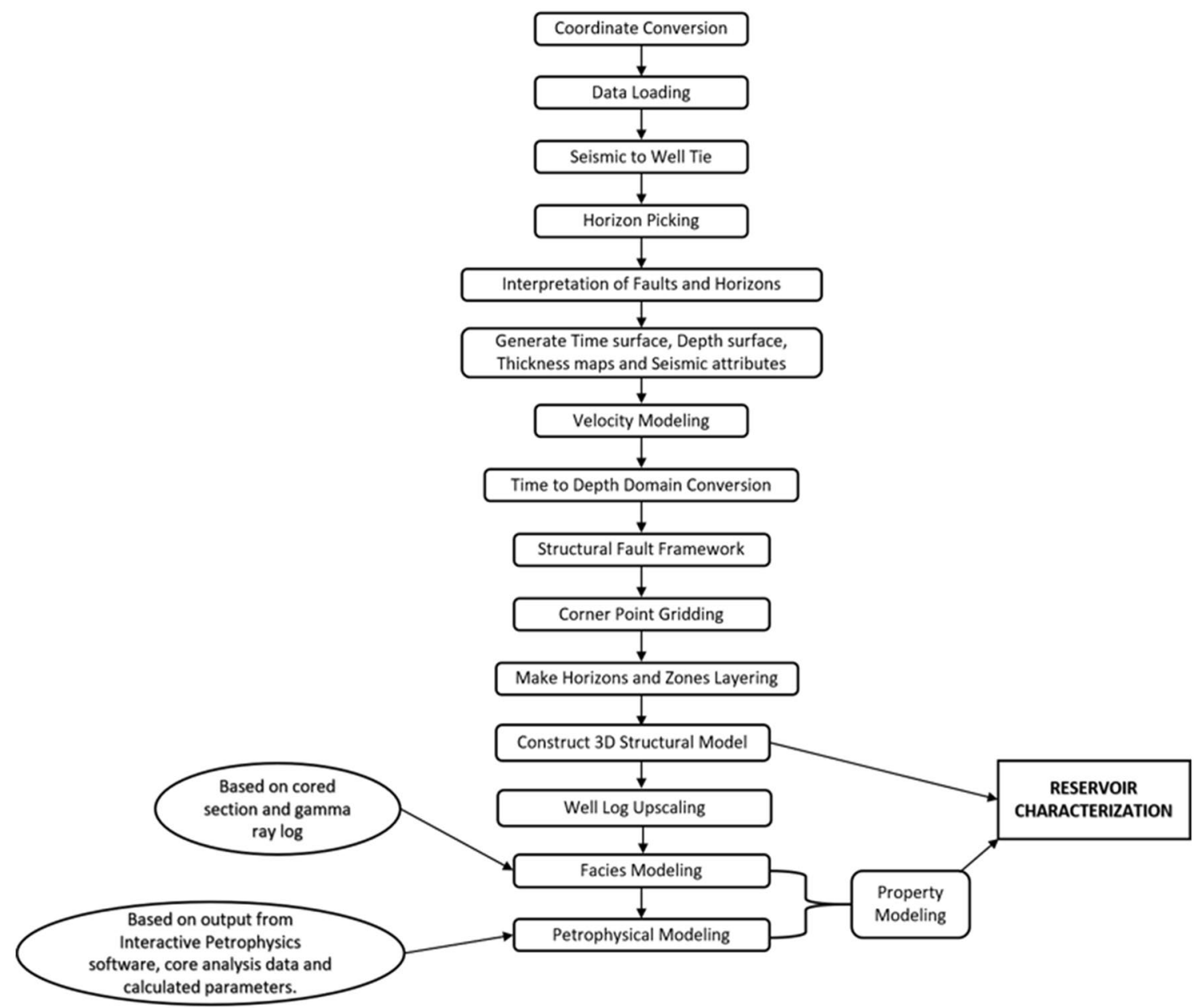

Fig. 3 Workflow of integrated modeling for the Mount Messenger Formation, Kaimiro-Ngatoro Field

where $\Phi \mathrm{D}$ and $\Phi \mathrm{N}$ are the density and neutron porosities of the formation, respectively. The effective porosity is then estimated using the equation of Schlumberger (1989):

$\Phi_{e}=\Phi t \times\left(1-V_{s h}\right)$

The Indonesian equation (Poupon and Leveaux 1971) was used for estimating the water saturation (SW) (Eq. 6). The hydrocarbon saturation (Shc) was calculated by deducting Sw from $100 \%$ saturation.

$S_{w}=\left\{\left[\left(\frac{V_{s h}^{2-V_{s h}}}{R_{s h}}\right)^{1 / 2}+\left(\frac{\Phi_{e}^{m}}{R_{w}}\right)^{1 / 2}\right]^{2} R_{t}\right\}^{-1 / n}$ where Rt is the total/true resistivity of the formation and $n$ is the saturation exponent.

$S_{h c}=100-S_{w}$

For estimating the net reservoir and pay thicknesses, cutoff values were applied, porosity $\leq 10 \%$, shale volume $\geq 50 \%$, water $\geq 50 \%$. The net to gross (for pay thickness) has been obtained by dividing the net pay thickness to the gross reservoir thickness (Worthington 2010). The permeability values were taken from routine core analysis data and plotted on the permeability versus depth graph using the data available for the wells, and then, it was converted to LAS file using Neuralog software. All petrophysical logs were imported and upscaled in the Petrel software domain, and then sequential Gaussian simulation (SGS) algorithm was applied to develop 
Fig. 4 Depth structure map of the top of the Mount messenger Formation. The red and orange color represents the higher structure, and the blue and purple indicates the lower areas. The depth structure gradually lowers in northwest

Fig. 5 Isochore map of the Mount Messenger formation
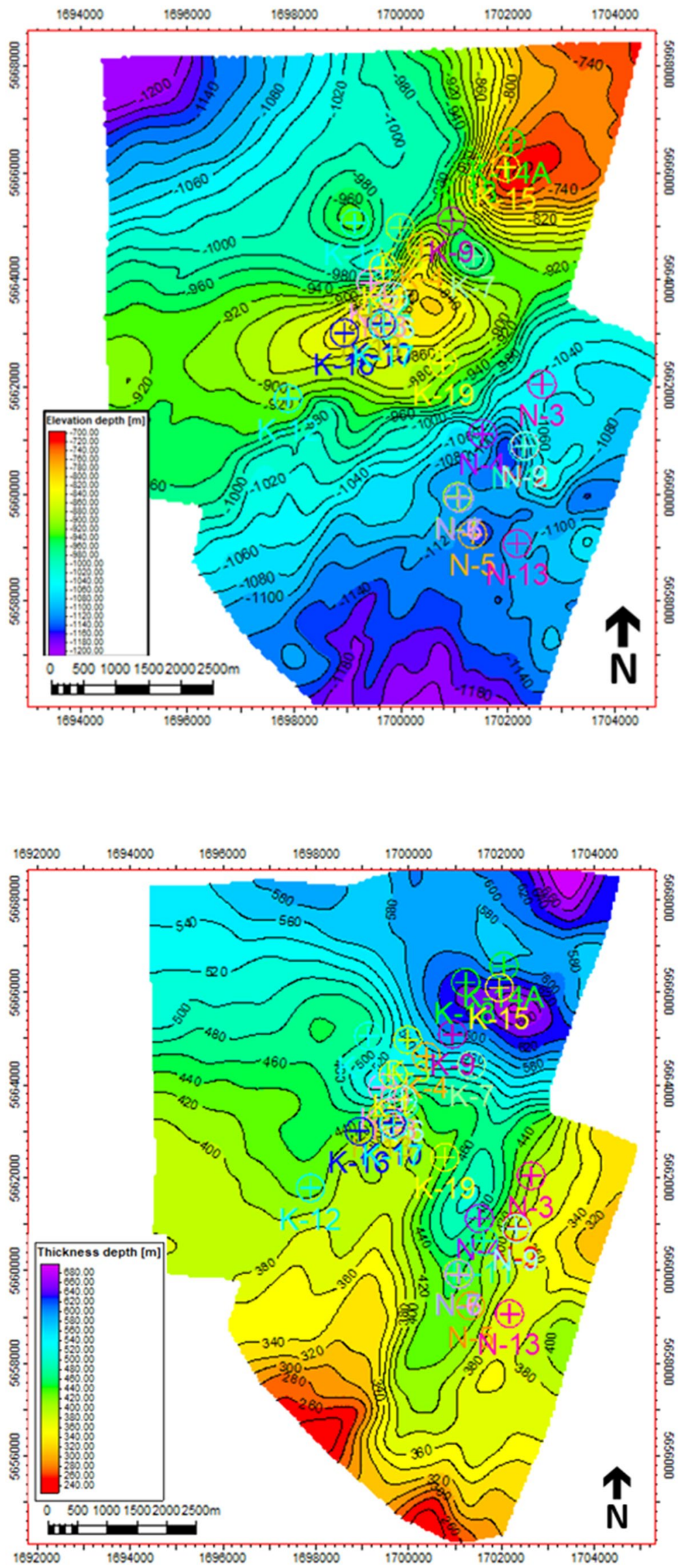

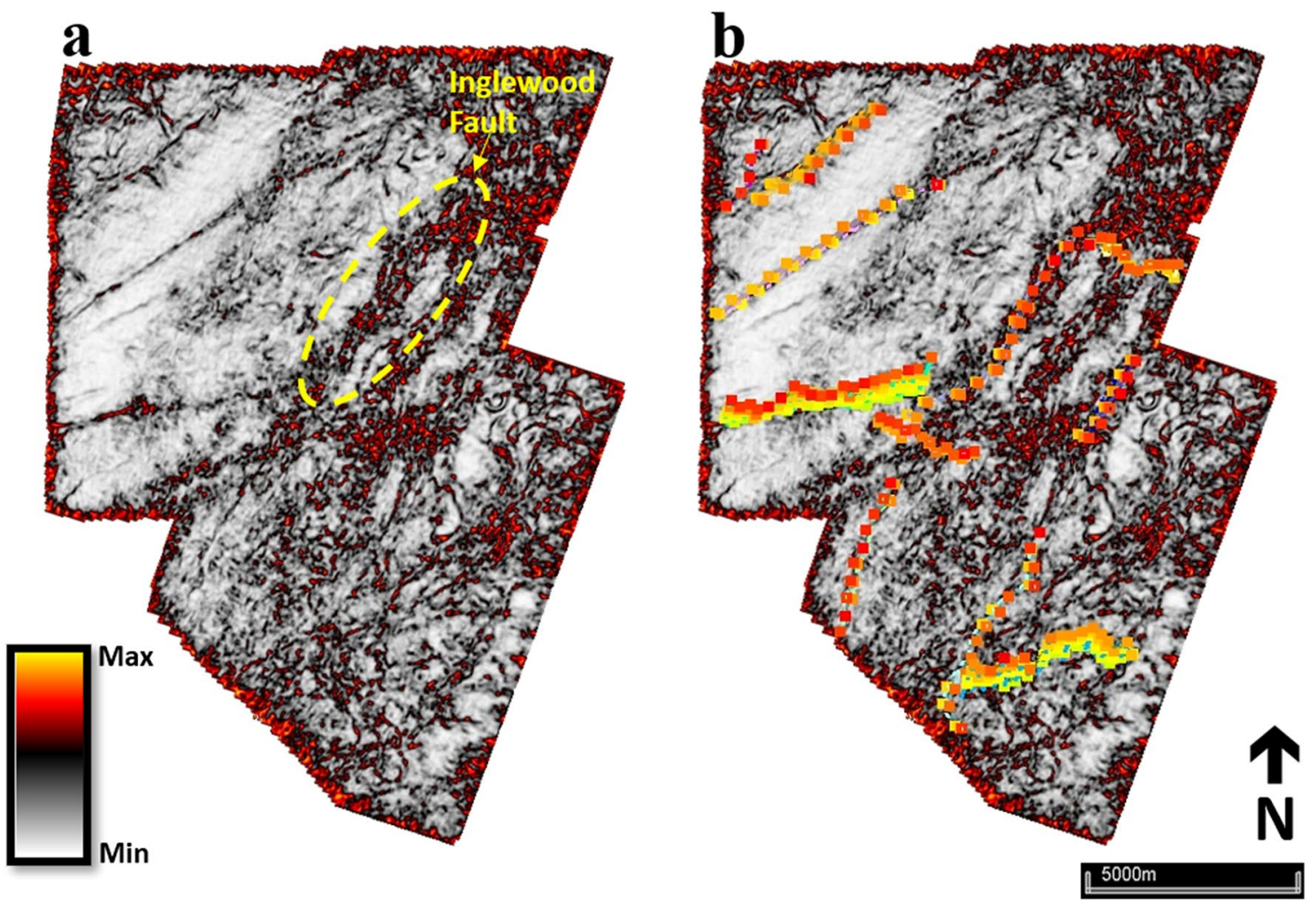

Fig. 6 Variance distribution at $1.2 \mathrm{~s}$ through the Kaimiro-Ngatoro Field. a Showing the major fault, Inglewood fault. b variance map with interpreted faults

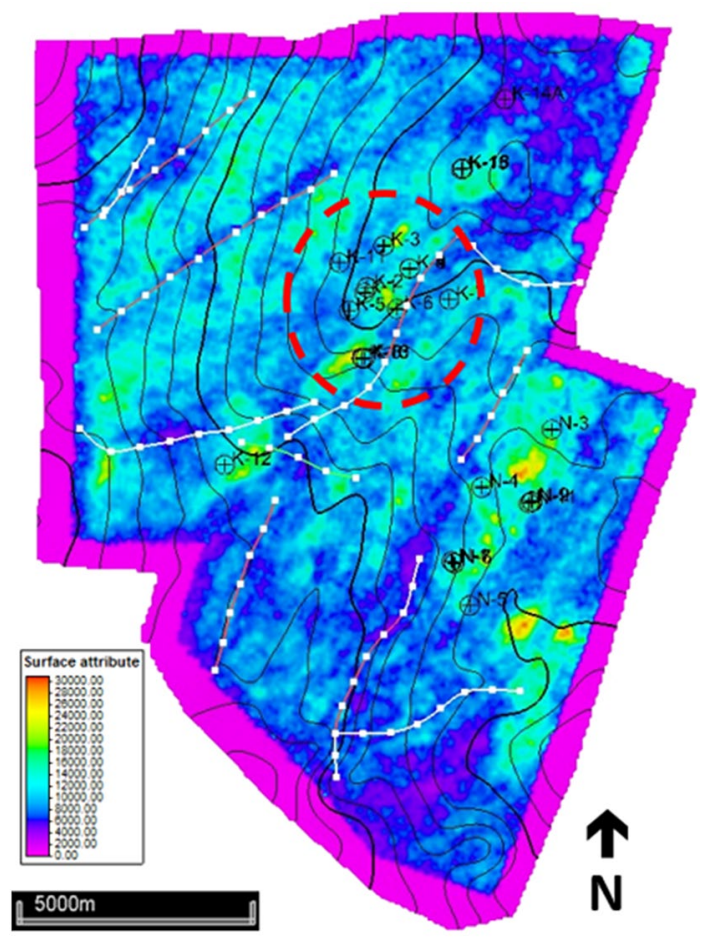

Fig. 7 RMS amplitude of Mount Messenger Formation porosity, permeability, water saturation, hydrocarbon saturation, net to gross and volume of shale modeling following Qadri et al. 2019; Islam et al. 2020.

Some equations were applied in calculating properties to generate models such as reservoir quality index (RQI) model and flow zone indicator (FZI) model. The pore volume to matrix volume parameter (Amaefule et al. 1993) is known as the normalized porosity index $\left(\mathrm{NPI}, \Phi_{\mathrm{z}}\right)$ that can be obtained through this formula:

$\Phi z=\Phi /(1-\Phi)$

The porosity and permeability are related to each other in the form of the reservoir quality index (RQI) which can be shown as:

$\mathrm{RQI}=0.0314 \sqrt{\mathrm{K} / \Phi}$

where permeability, $\mathrm{K}$, is measured in $\mathrm{mD}$ and porosity, $\Phi$, is measured in fraction.

FZI parameter integrates the geological attributes of texture and mineralogy that discriminates the hydraulic flow units (Amaefule et al. 1993). The flow zone indicator (FZI) can be shown as:

$\mathrm{FZI}=\mathrm{RQI} / \mathrm{NPI}$

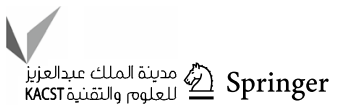



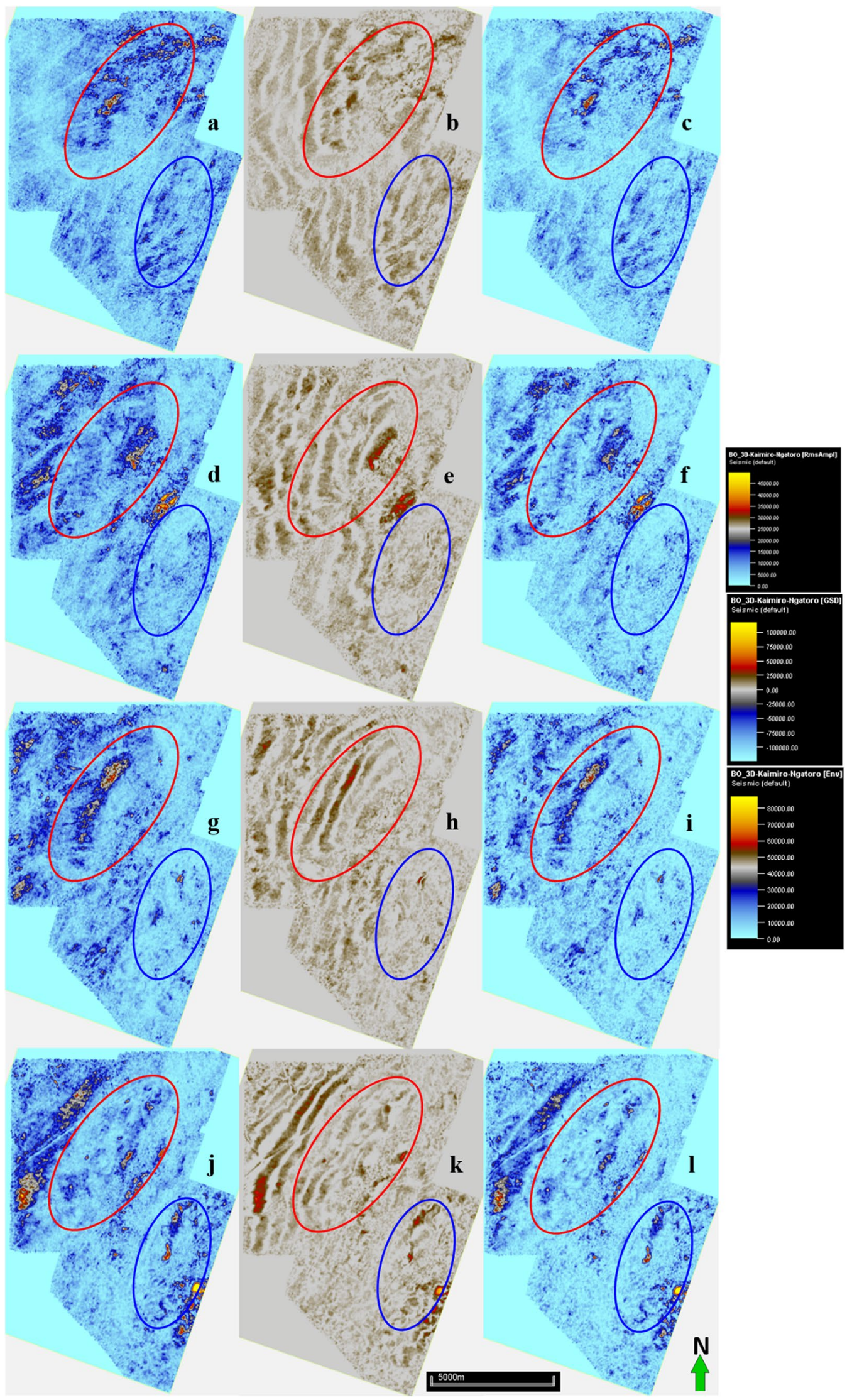

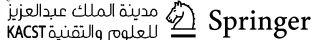


४Fig. 8 RMS amplitude (RmsAmpl), generalized spectral decomposition (GSD) and envelope (Env) seismic attributes of Mount Messenger Formation at different time slice, $\mathbf{a}, \mathbf{b}$ and $\mathbf{c}$ RmsAmpl, GSD and Env at $0.96 \mathrm{~s}, \mathbf{d}$, e and $\mathbf{f}$ RmsAmpl, GSD and Env at $1.07 \mathrm{~s}, \mathbf{g}, \mathbf{h}$ and i RmsAmpl, GSD and Env at $1.14 \mathrm{~s}, \mathbf{j}$, $\mathbf{k}$ and $\mathbf{l}$ RmsAmpl, GSD and Env at $1.26 \mathrm{~s}$. Red oval shape highlights Kaimiro wells area and blue oval highlights Ngatoro wells area

\section{Results and discussion}

\section{Subsurface map construction}

\section{Depth surface map}

In the study area, depth surface map reveals the structure of the formation of interest. Figure 4 shows the depth surface map (depth values displayed are in true vertical depth) of
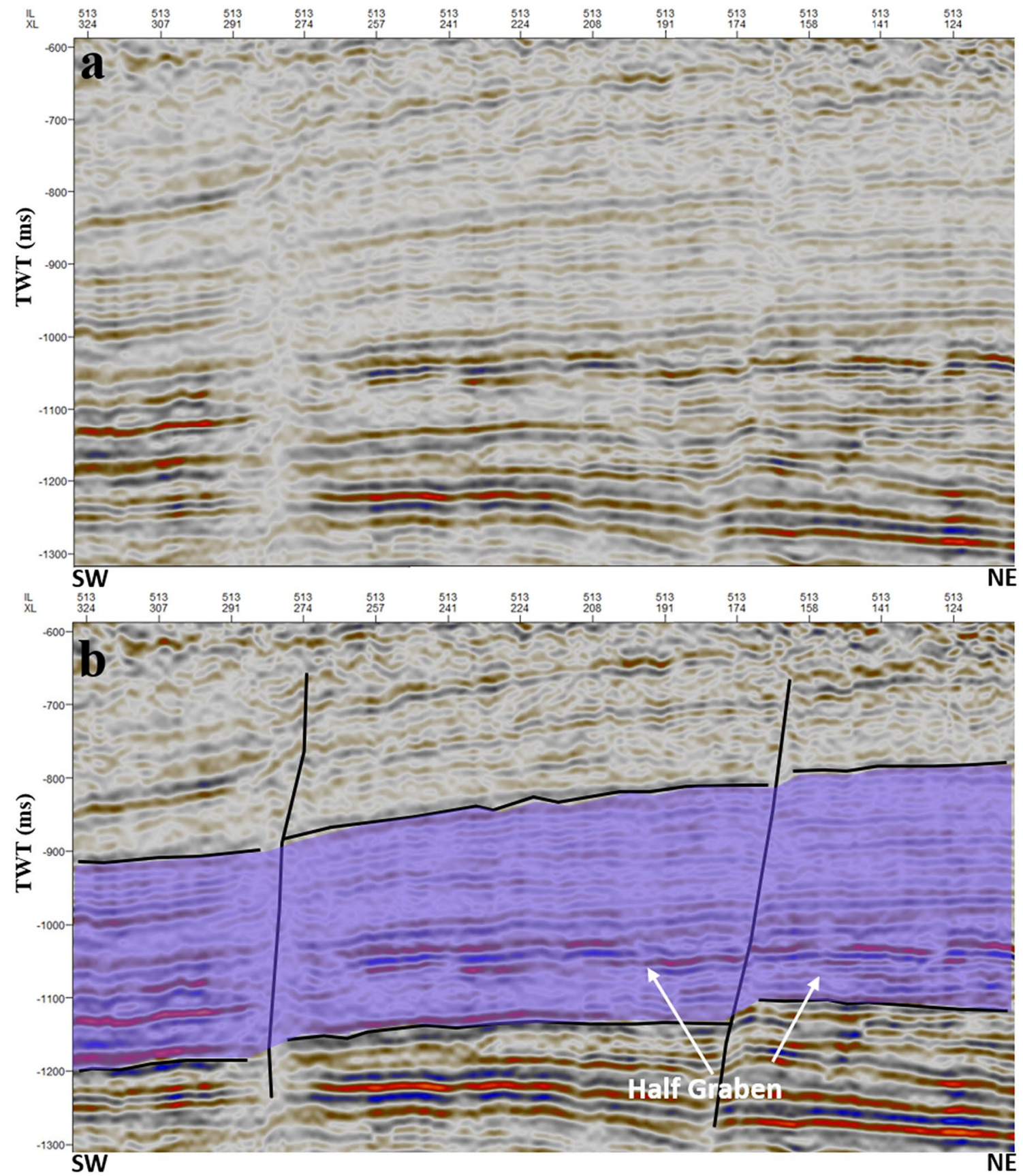

Fig. 9 a Uninterpreted seismic section of "inline 513" from original seismic cube. b Interpreted seismic section of "inline 513" from seismic cube where trace AGC (automatic gain control) seismic attribute was applied for better resolution. SW and NE indicate southwest and northeast. Vertical scale is two-way travel time in milliseconds 

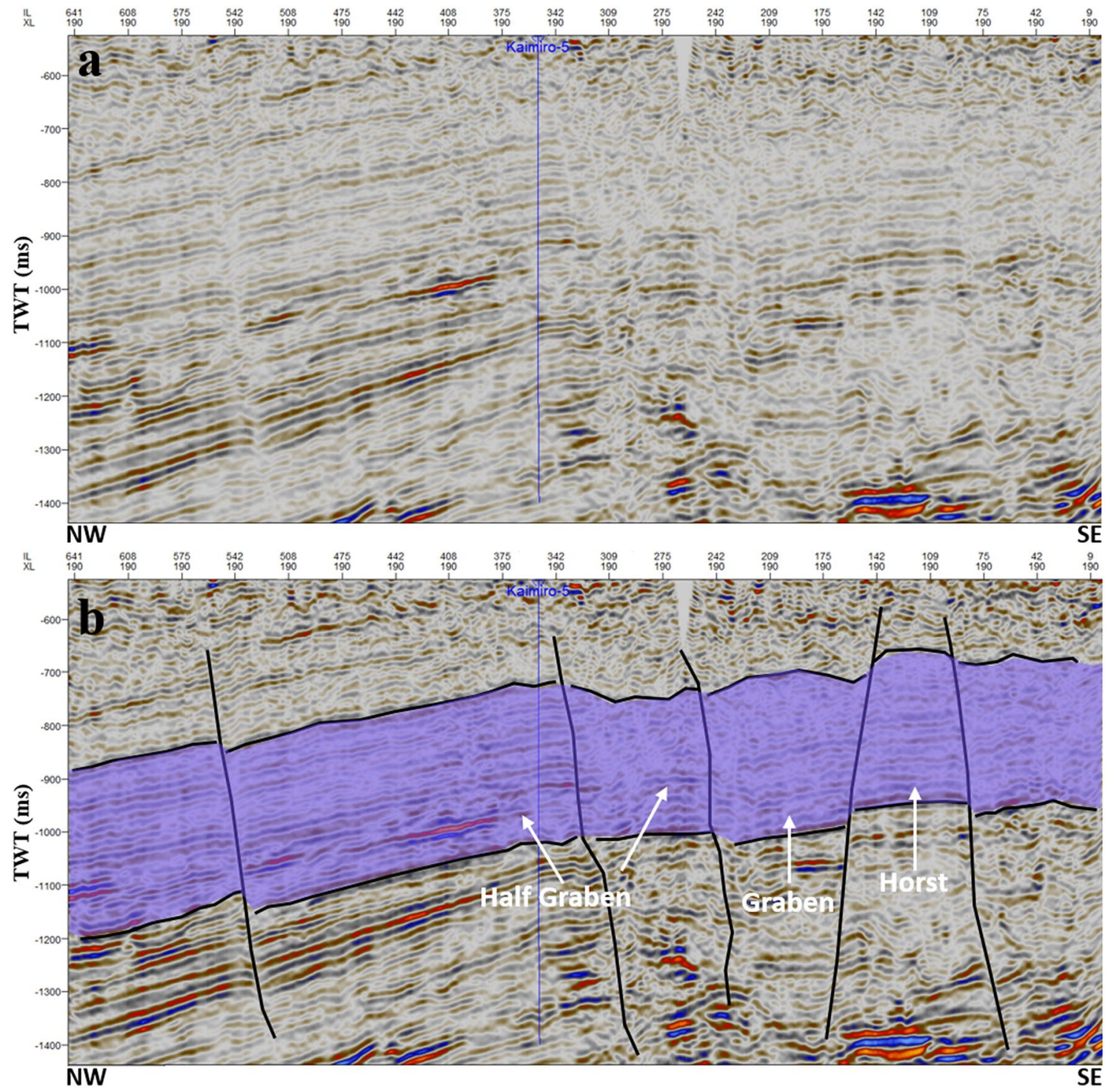

Fig. 10 a Uninterpreted seismic section of "xline 190" from original seismic cube. b Interpreted seismic section of "xline 190" from seismic cube where trace AGC (automatic gain control) seismic attribute

the top Mount Messenger Formation, indicating the position of highs and lows, where the depth structure gradually lowers toward northwest since the east and southeast hinterlands were raised during tectonic uplift through central New Zealand (King et al. 1993). The enormous volumes of Late Miocene (Mount Messenger Formation) sediments were transported toward west and northwest due to gravity flows from the east and southeast (Kristian Helle 2003; Grahame 2015). A four-way dip closure anticline is observed in the Kaimiro Field, and majority of the Kaimiro wells were drilled in this area. was applied for better resolution. NW and SE indicate southwest and northeast. Vertical scale is two-way travel time in milliseconds

\section{Isochore map}

The isochore map of Mount Messenger Formation is shown in Fig. 5. The spatial variation in depth thickness within the Mount Messenger Formation ranges from 223 to $698 \mathrm{~m}$. The color variation in the thickness map features two contrasting trends, indicating that the areas of purple and blue are thicker than the areas in red and orange. The Mount Messenger Formation is best developed in the north, northeast and gradually decreases in thickness toward the south (Fig. 5), which perfectly matches with King and Thrasher (1996). As 


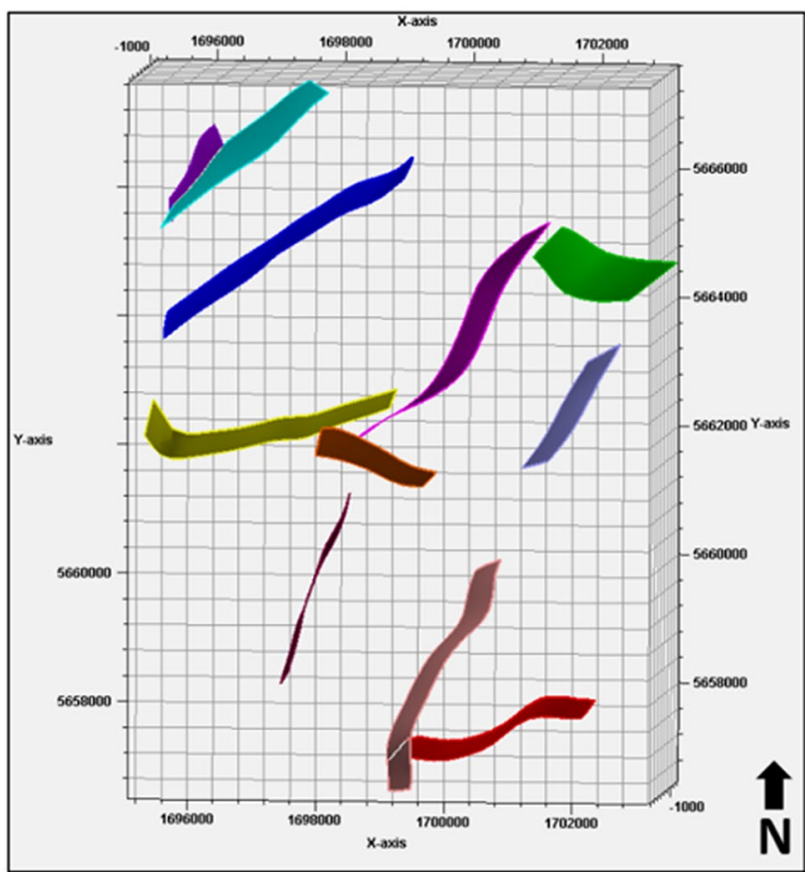

Fig. 11 3D map view of fault surfaces of Mount Messenger Formation, Kaimiro-Ngatoro Field mentioned in Sect. 5.1.1, the sediments were transported from east-southeast and settled in west-northwest; Fig. 5 shows that the thickness slowly increases from southeast to northwest with values $320-540 \mathrm{~m}$, respectively.

\section{Seismic interpretation and mapping}

\section{Seismic attribute analysis}

Variance attribute The variance attribute helps to identify geological elements like faults, channels and stratigraphic features. The mentioned geological features are visualized when variance coefficient is maximum, while low variance coefficient indicates good continuity between seismic traces (Marfurt et al. 1998; Abul Khair et al. 2012). Figure 6a\&b shows variance attribute at $1.2 \mathrm{~s}$ in the Kaimiro-Ngatoro Field. The major Inglewood fault and few minor faults are revealed from variance attribute (Fig. 6a) that completely matches with the interpreted faults in Fig. 6b. The faults are interpreted based on the offset of reflection events, poor image of near-vertical zones and irregular surface separating the reflection patterns on seismic sections.

RMS amplitude (root-mean-square), generalized spectral decomposition (GSD) and envelope (Env) attributes. RMS amplitude is a classical and most common seismic attribute used in reservoir characterization, which indicates the presence of hydrocarbons, of course not always. RMS
Fig. 12 3D Rose diagram showing the faults strike of Mount Messenger Formation, KaimiroNgatoro Field

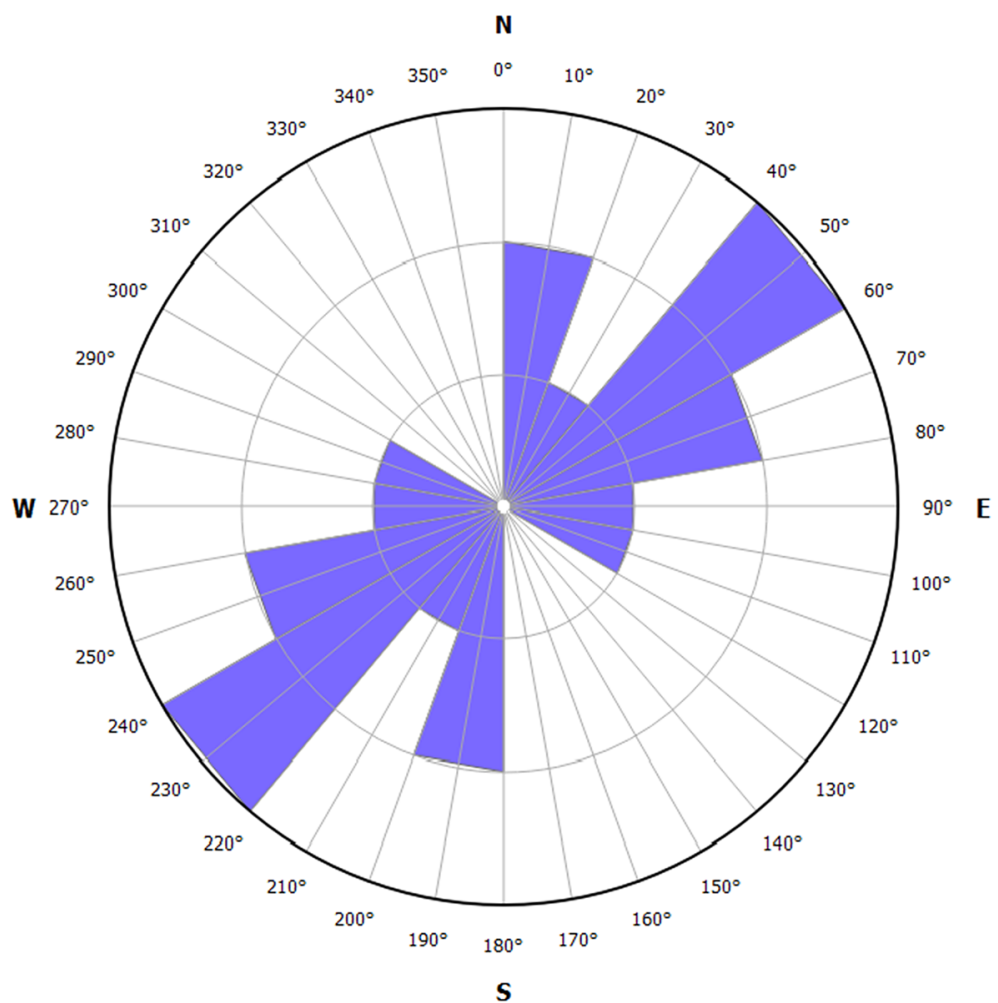

S 


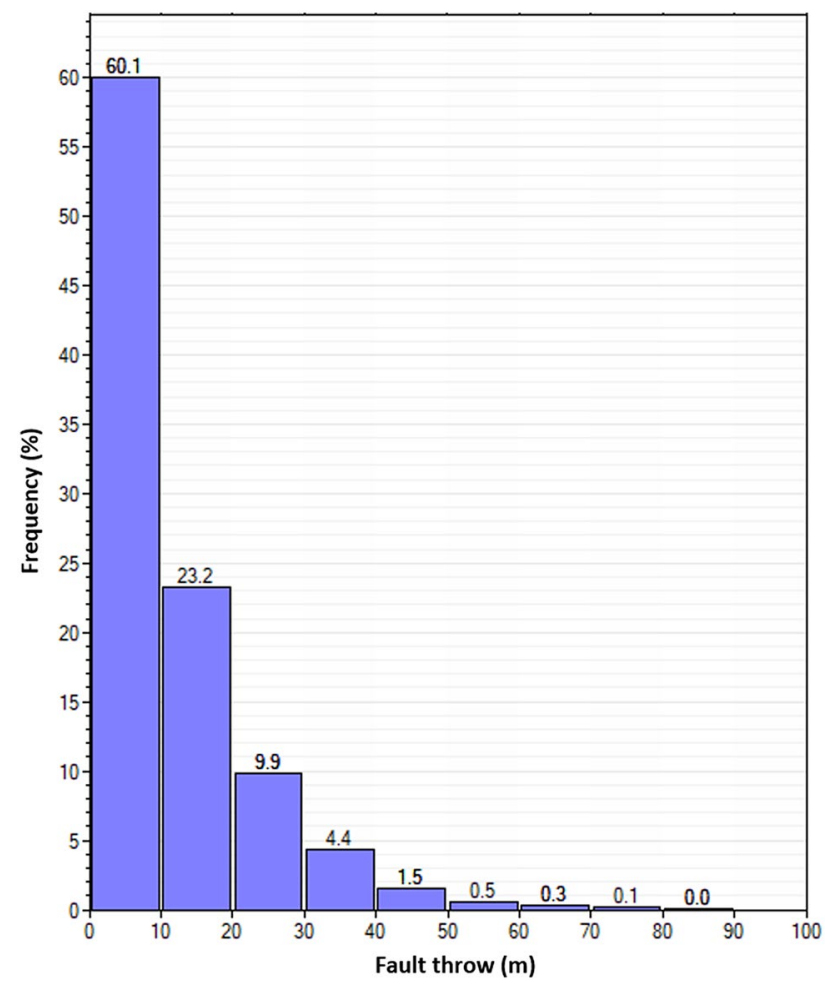

Fig. 13 Histograms of fault throw of Mount Messenger Formation, Kaimiro-Ngatoro Field

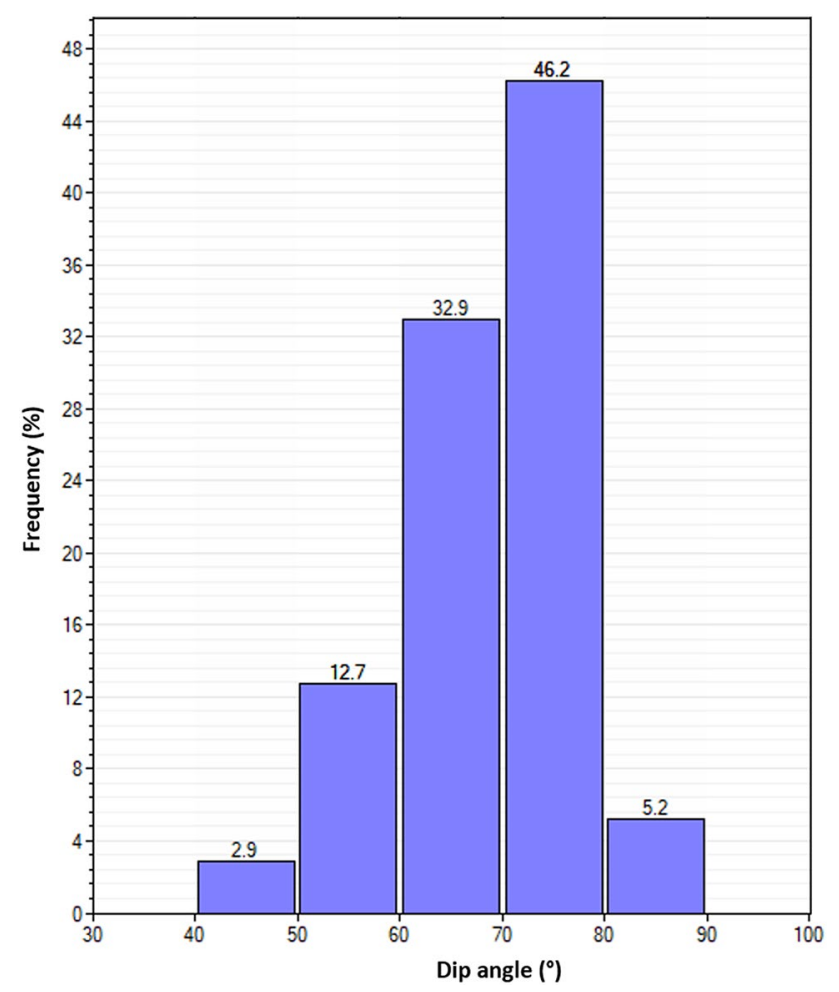

Fig. 14 Histograms of fault dip angles of Mount Messenger Formation, Kaimiro-Ngatoro Field amplitude map is extracted for Mount Messenger reservoir top (Fig. 7), which shows the strong amplitude anomalies exist at the central and little bit above central parts of the field, and also parts of the southeast corner. The area above central part of the field circled in red color (Fig. 7), where strong amplitude anomalies are noticed that correlates with the observed anticlinal structure (Fig. 4) in the KaimiroNgatoro Field. It is identified that the strong amplitude anomalies in RMS amplitude map are seen to occur close to the faults and therefore indicate that they are structurally controlled. The RMS amplitude attribute carried out in this study can be supported by the displayed wells, which were drilled at or close to the strong anomalies. To support the evidence of hydrocarbon presence through RMS amplitude surface attribute, time slices at $0.96 \mathrm{~s}$ (Fig. 8a, b, c), $1.07 \mathrm{~s}$ (Fig. 8d, e, f), 1.14 s (Fig. 8g, h, i) and $1.26 \mathrm{~s}$ (Fig. 8j, k, 1) for RMS amplitude, generalized spectral decomposition and envelope seismic attributes are generated (Kaimiro area is highlighted in red oval shape and Ngatoro area is highlighted in blue oval shape). Strong amplitude anomalies are observed in different parts of the Mount Messenger Formation at each time slice. Overall, from all the time slices, it is perceived that in the Kaimiro Field majority of hydrocarbon presence is from the upper section of the Mount Messenger Formation (from time slices $0.96 \mathrm{~s}, 1.07 \mathrm{~s}, 1.14 \mathrm{~s}$ ), whereas in the Ngatoro Field, the hydrocarbon presence is indicated from the lower section of the formation (from time slice $1.26 \mathrm{~s})$.

\section{Fault mechanism}

Fault mechanisms play a vital role, since they control not only the evolution of basins or formations, but also, they involve in crucial processes such as hydrocarbon entrapment, seals and development of hydrocarbon migration pathways (Sykes 2012). The complex and composite morphology of the Taranaki Basin is resulting from multiple episodes of tectonic activity. King and Thrasher (1996) described three phases of tectonic deformation, which were controlled by distinct plate boundary kinematics. The Mount Messenger Formation belongs to the Oligocene to recent active marginal basin phase. In this study, the generated 3D structural model comprises of interpreted two reservoir horizons and eleven faults. In the current study, it is noticed that the nature and complexity of faults is similar throughout the Mount Messenger Formation in Kaimiro-Ngatoro Field, which is explained by generating two seismic sections across the structural model (Fig. 9, 10). Half-grabens are observed from "inline 513" (Fig. 9); Fig. 10 shows grabens, half-grabens and horst bounded fault blocks of "xline 190" because of an extensional relaxation and normal faulting happened after compressional tectonics phase during Miocene. Mostly these normal faults have structural trend of NE-SW, while 

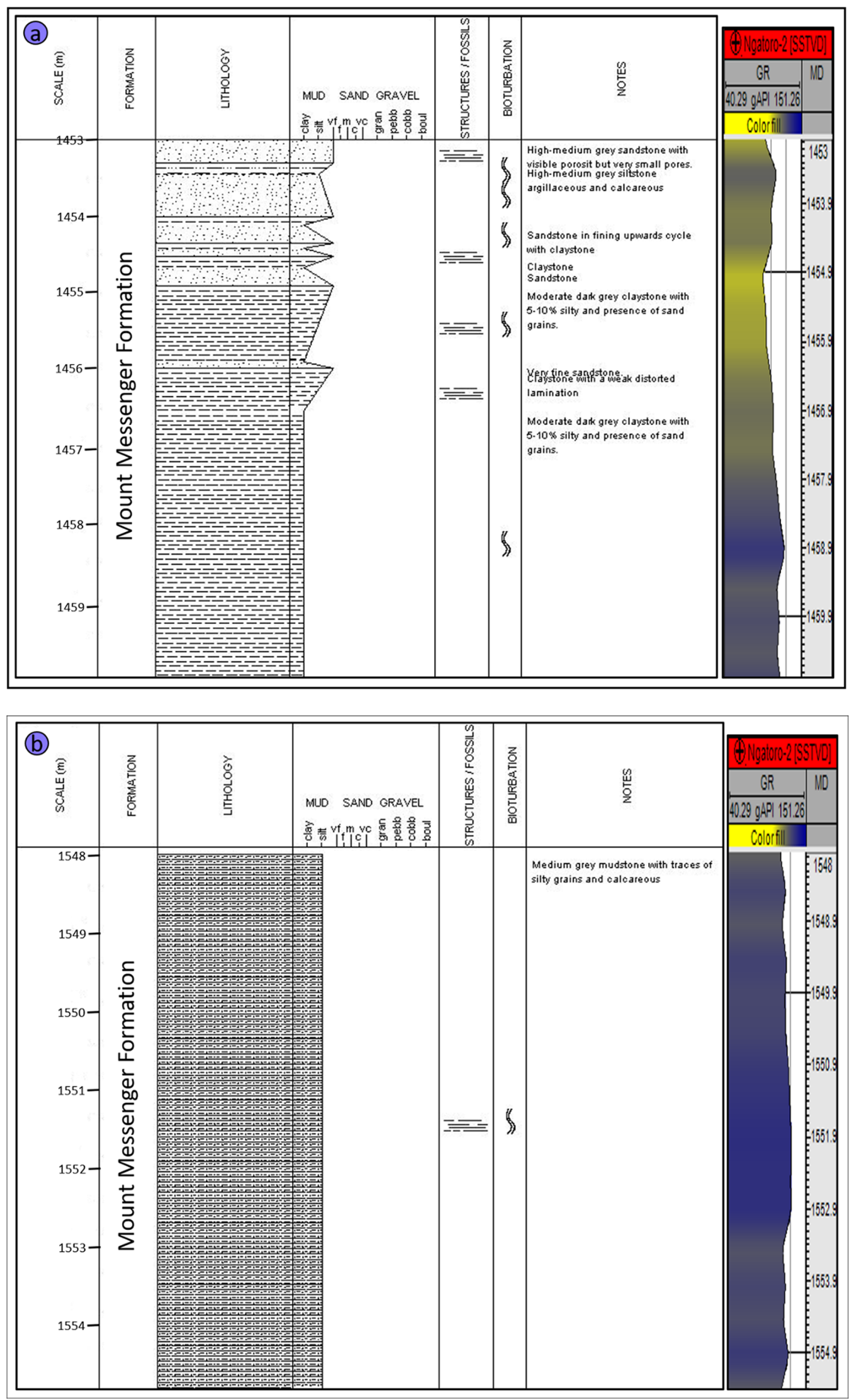

Fig. 15 a Lithology log and gamma ray log of Ngatoro-2 well from depths 1453-1459.96 m, b lithology log and gamma ray log of Ngatoro-2 well from depths 1548-1554.91 m, c lithology log, gamma ray log from depths of 1572.77$1591.16 \mathrm{~m}$, and core photographs from depths $1578-1584 \mathrm{~m}$ of Ngatoro-2 well 


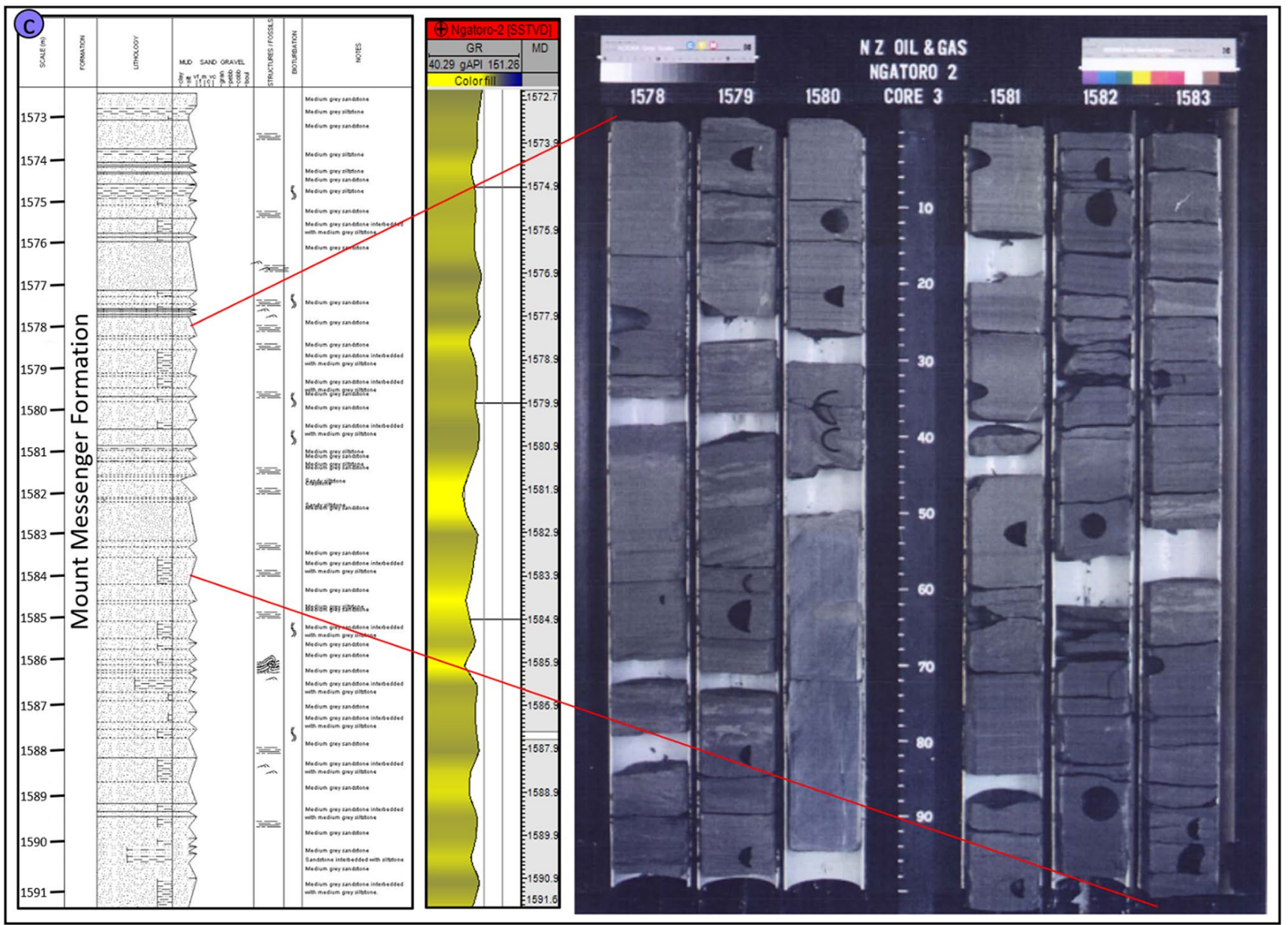

Fig. 15 (continued)

only one or two have NW-SE trends (Fig. 11). Normal faults affecting the Mount Messenger reservoir are all thought to be sealing as it is a producing reservoir and seen as compartmentalized; this could be one of the reasons to drill many wells in the field.

\section{Fault geometry distribution}

The strike, dip angle, fault throws and their relationship of eleven interpreted faults that penetrate Mount Messenger Formation are explained here. The rose diagram in Fig. 12 discloses that most of the interpreted faults are trending with preferred orientation of NW-SE (can see in Fig. 11), few almost with N-S trend. The relationship between fault frequency $(\%)$ and fault throw $(\mathrm{m})$ through histogram is shown in Fig. 13, revealing that $60.1 \%$ of faults have throw values less than $10 \mathrm{~m}$, and only $0.9 \%$ of faults have throw values between 50 and $80 \mathrm{~m}$. Histogram displaying relationship between fault frequency $(\%)$ and dip angle $\left({ }^{\circ}\right)$ is shown in Fig. 14, which specifies that the $46.2 \%$ (highest) of the interpreted faults are noticed between 70 and $80^{\circ}$, followed by
$32.9 \%$ of the faults are between 60 and $70^{\circ}$; this explains that majority of faults in this field are steep.

\section{Facies analysis and depositional environments}

\section{Analysis of sedimentological features relationship and lithological distribution}

In this study, five lithofacies with various sedimentary structures were identified from the available cores (core photographs and core descriptions), namely sandstone, sandy siltstone, siltstone, claystone and mudstone (Fig. 15a, b, c; Fig. 16). Several differences occur between cores and also stratigraphy within the core. All cores are characterized by their muddy nature and are dominated by fine-grained claystone, mudstone and siltstone lithofacies, whereas sandstone comprises a volumetrically small proportion of all the cores. Many of the lithofacies can be equated to Bouma-type subdivisions of turbidite units (Ta to Te) (Bouma 1962).

Massive sandstone ( $\mathrm{Ta}$ ): It comprises well-sorted, fine to very fine-grained sandstone (Fig. 17a, 18). Bases to the 

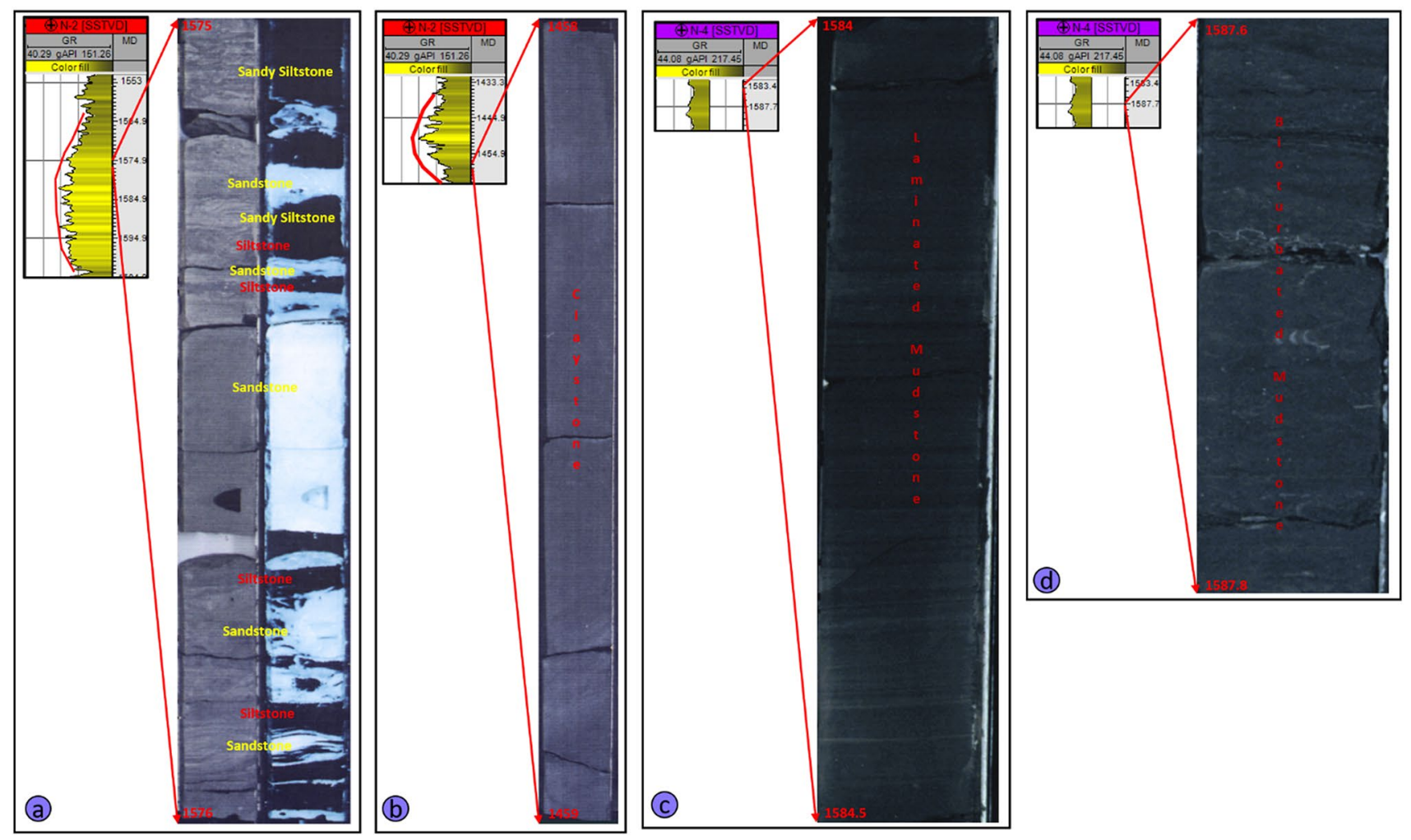

Fig. 16 Five identified lithofacies (sandstone, sandy siltstone, siltstone, claystone and mudstone) are shown in different core photographs from $\mathrm{N}-2$ and N-4 wells. Units are in meters
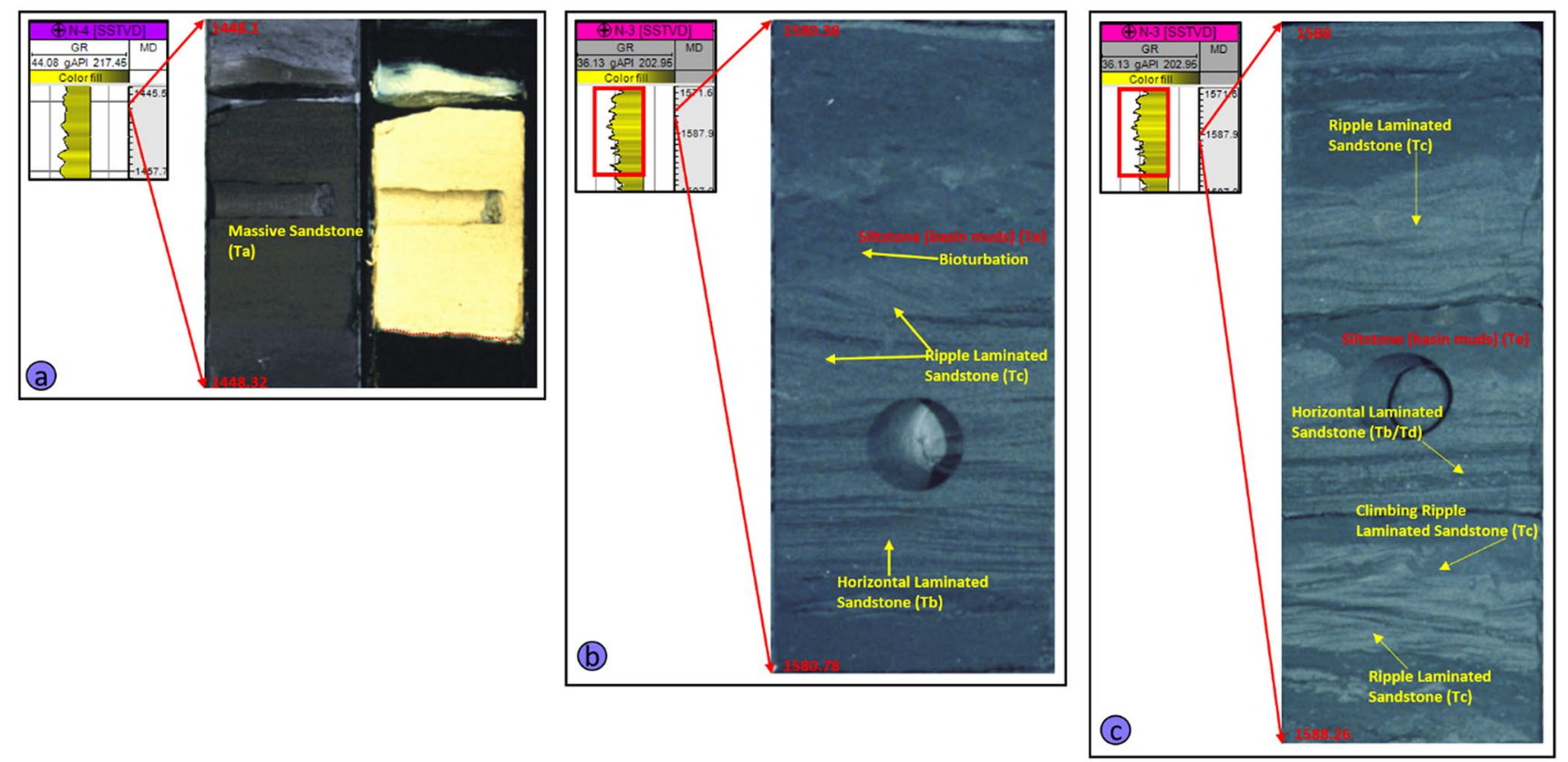

Fig. 17 Bouma-type turbidite subdivision units (Ta to Te) from core photographs of wells N-3 and N-4. Units are in meters 


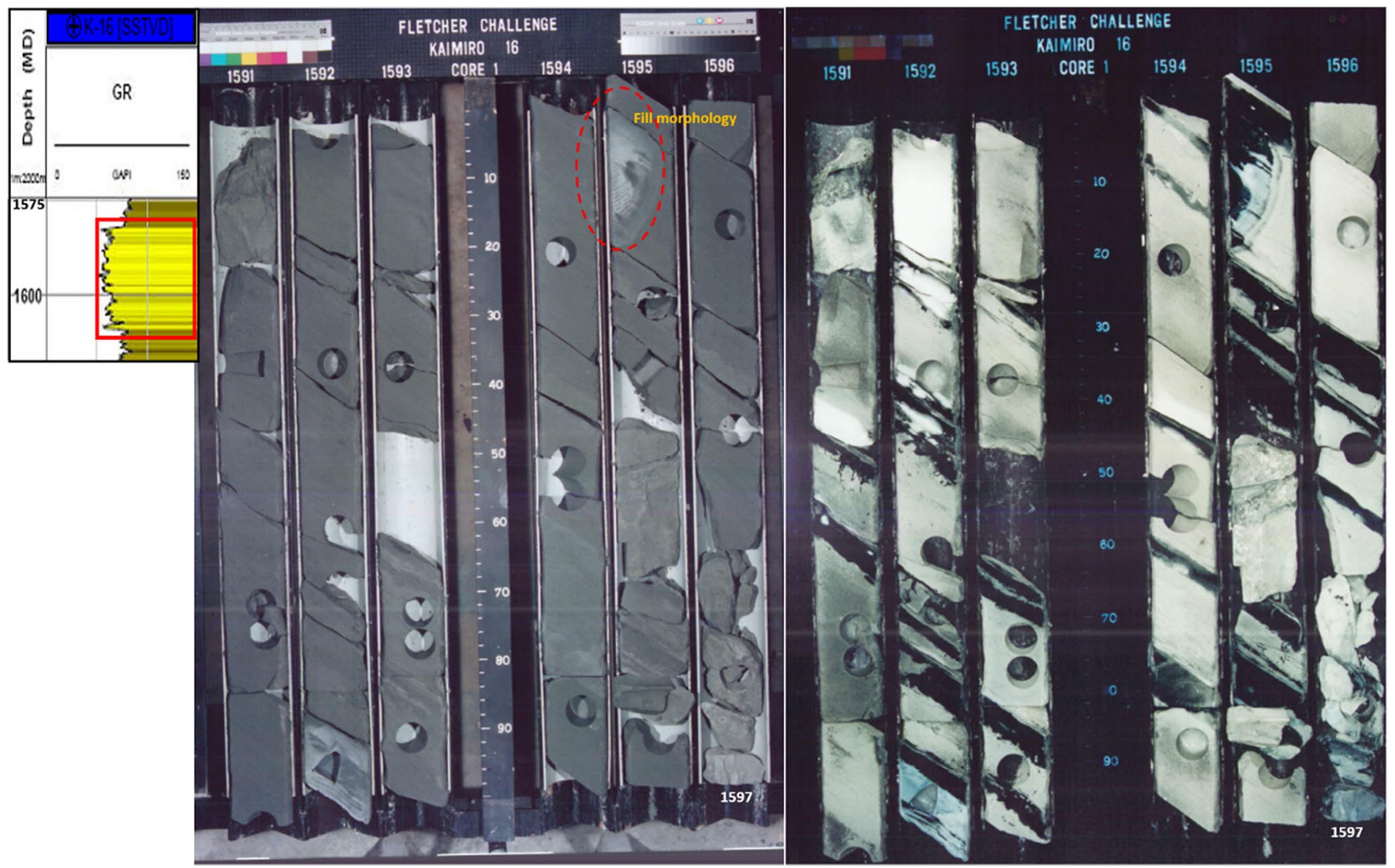

Fig. 18 A core photograph under white light (left), ultraviolet light (right) showing example of basin floor fans and massive sandstones (could be Bouma subdivision Ta) from interval 1591-1597 m of well

beds are sharp (Fig. 18) and erosive (Fig. 17a), where tops of beds are planar, irregular and gradational with overlying units. Sandstones lack normal grading, a feature which is unlike the classical Bouma A division turbidites; however, not all turbidite A divisions in the literature show a normal graded subdivision. Horizontally laminated sandstone $(\mathrm{Tb})$ : It consists of well-sorted, dominantly very fine-grained sandstone, and they have sharp, planar bases and tops (Fig. 17b; Fig. 19, 20). Figure 17b shows a welldeveloped horizontal lamination sedimentary structure with overlying ripple-laminated sandstone. Ripple and climbing ripples are laminated sandstone (Tc): It contains well-sorted, primarily very fine-grained sandstone (Fig. 17b, c; Fig. 19, 20 ). Bases to the beds are planar or slightly erosive into underlying lithologies; tops are planar or slightly irregular. Figure $17 \mathrm{c}, 19$ shows that ripple-laminated units sometimes pass upward into climbing ripple-laminated interval, indicating an increase in sediment supply. Basin muds (Te): These include mudstone, claystone and siltstone lithofacies (Fig. 16; Fig. 17b, c; Fig. 21), where some of them are in large part homogeneously bioturbated, though some units show less bioturbated intervals several $\mathrm{mm}$ to $\mathrm{cm}$ thick, and some of them are laminated.
Kaimiro-16 (K-16), and the red rectangle in the gamma ray represents basin floor fans (Mitchum et al. 1993)

Although individual beds can be interpreted as turbidites and equated to the Bouma divisions ( $\mathrm{Ta}, \mathrm{Tb}, \mathrm{Tc}, \mathrm{Td}$, $\mathrm{Te}$ ), clear Bouma cycles from Ta to Te are not observed. Anyhow the complete Bouma cycle in many cases of deepwater turbidites is absent due to many factors such as the erosion by the following cycle, location of the cored section. The normally graded sandstone Ta intervals are not well represented. The horizontal laminated and ripple/climbing ripple-laminated intervals likely represent Bouma $\mathrm{Tb}$ to Tc divisions, and the overlying bioturbated/laminated mudstone/siltstone/claystone represents Bouma Te (hemipelagic/pelagic) interval. It is not clear whether true Bouma Td-laminated sandstones occur, since they may equate with the Tb-laminated sandstones.

\section{Electrofacies distribution and correlation of the Mount Messenger Formation}

Gamma-ray and SP logs of five wells (K-4, K-8, K-10, K-11, N-7) (Fig. 22) from Kaimiro-Ngatoro Field were chosen to study the stratigraphic units of the Mount Messenger Formation. The succession of the formation was divided into two stratigraphic units, which were defined by distinct log 


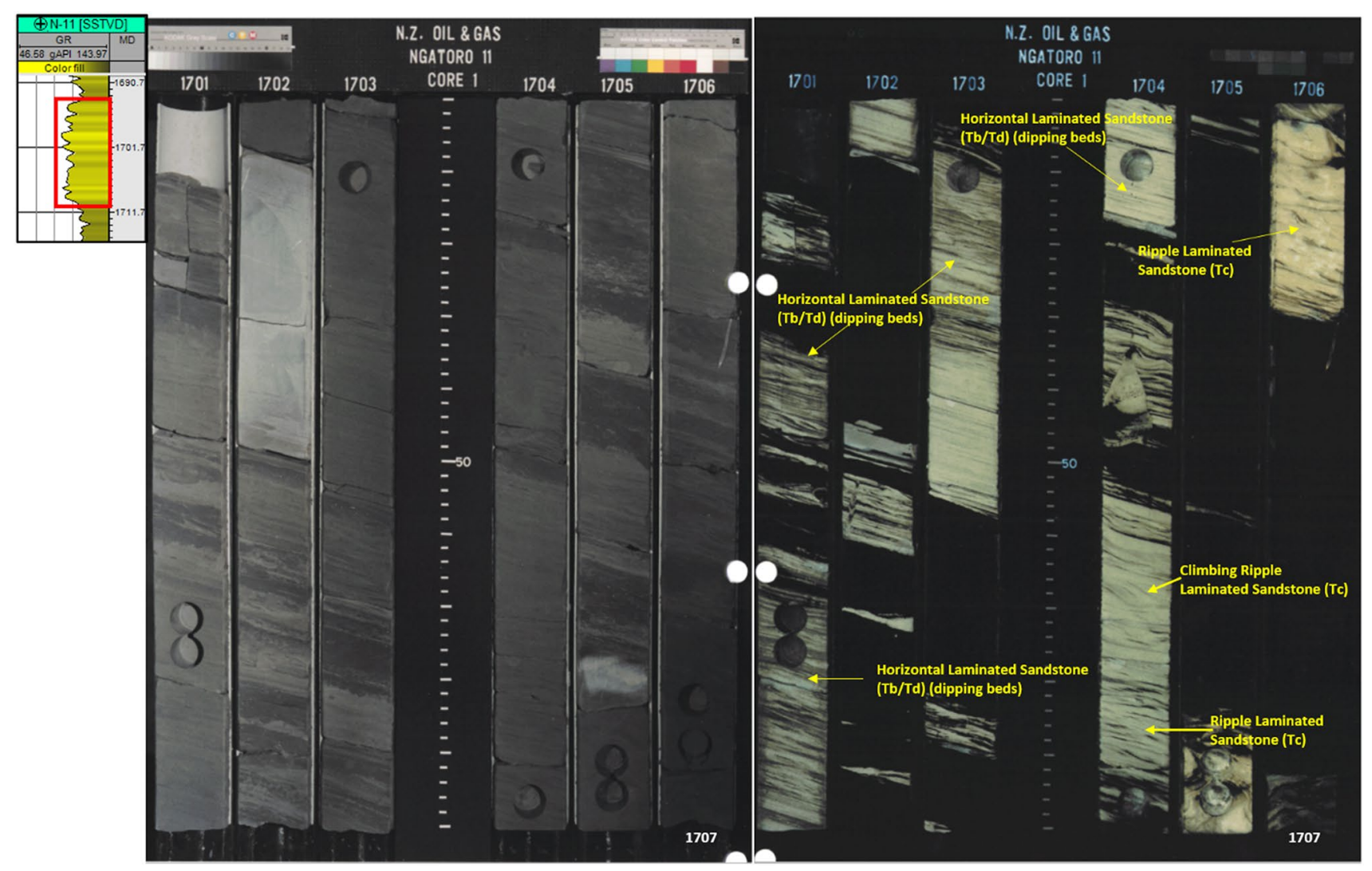

Fig. 19 A core photograph under white light (left), ultraviolet light (right) showing example of basin floor fans and sandstones (of Bouma subdivision $\mathrm{Tb} / \mathrm{Td}$ and $\mathrm{Tc}$ ) from interval $1701-1707 \mathrm{~m}$ of

character. The upper portion of the formation is slope fan units, and the lower section is basin floor units. Although both logs help to identify the depositional environments, Fig. 22 explains that SP log is much better to distinguish between slope fan and basin floor fan beds than gamma-ray $\log$.

The basin floor fans are depicted by a well-developed blocky motif in gamma-ray and SP logs (Mitchum et al. 1993). The thickness of basin floor fans is approx. 210$450 \mathrm{~m}$, and it consists of two types of sandstone beds, thickbedded sandstone and thin-bedded sandstone (Fig. 22). Figure 18 represents the thick-bedded sandstones of basin floor fans with thickness less than $1.0 \mathrm{~m}$ (fill morphology is observed), where Fig. 19 shows the thin-bedded sandstones with thickness less than $0.6 \mathrm{~m}$. In most of the wells, the basin floor fans sand bed thickness decreases and the sand quality declines (gamma-ray value increases). The slope fans are portrayed by a crescent-shaped or bell-shaped log motif in gamma-ray and SP $\operatorname{logs}$ (Mitchum et al. 1993). The thickness of basin floor fans is approx. 135-315 m, and it comprises of sandy intervals (channel-levee complex) interbedded with siltstone/claystone/mudstone. Figure 20 represents thin-bedded sandstones with intercalations of siltstone, well Ngatoro-11 ( N-11), and the red rectangle in the gamma ray represents basin floor fans (Mitchum et al. 1993)

and its thickness is less than $0.3 \mathrm{~m}$. Figure 22 shows slope fans consist larger portion of basin muds when compared to basin fans. Both basin floor and slope fans comprise of sedimentary structures such as horizontal lamination and ripple/climbing ripple lamination (Fig. 19, 20).

\section{Depositional environment relationships and reservoir units within sedimentary facies scheme}

It is crucial to examine the two types of submarine system in terms of reservoir characteristics and hydrocarbon exploration, since they have distinct petrophysical parameters and depositional characteristics. Some of the slope and basin floor fan units are chosen from K-15, K-16, K-18, N-2, N-3, $\mathrm{N}-7, \mathrm{~N}-9$ wells based on $\log$ character to study the petrophysical properties with the help of routine core analysis (Fig. 23).

In slope fan deposits (from wells K-15, K-18 and N-2), the porosity values vary from 11.1 to $29.7 \%$ showing fair to excellent (Levorsen 1967) results, whereas the values of permeability ranging from 0.04 to $368 \mathrm{mD}$ (Levorsen 1967) represent poor to very good quality. The hydrocarbon saturation values are varying from 12.1 to $62.80 \%$ which shows poor to 


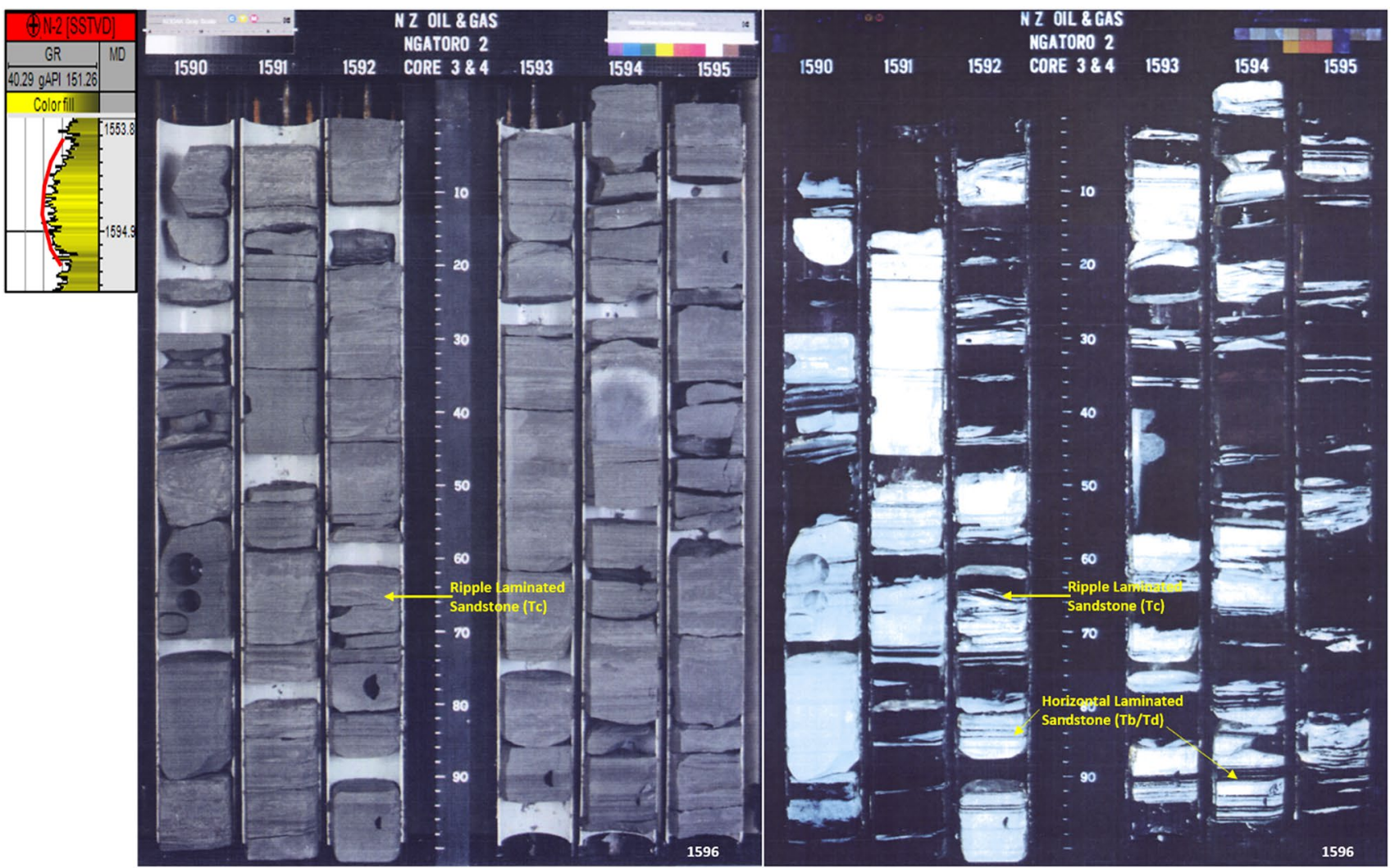

Fig. 20 A core photograph under white light (left), ultraviolet light (right) showing example of slope fans and sandstones (of Bouma subdivision $\mathrm{Tb} / \mathrm{Td}$ and $\mathrm{Tc}$ ) from interval $1590-1596 \mathrm{~m}$ of well Ngatoro-2
$(\mathrm{N}-2)$, and the red crescent shape in the gamma ray represents slope fans (Mitchum et al. 1993)

\section{D structural modeling, facies modeling, petrophysical modeling and implication of 3D modeling on field development.}

\section{D Structural Modeling}

ability values vary from 0.14 to $542 \mathrm{mD}$ which represents poor to very good results. The hydrocarbon saturation varies from 61.8 to 67 showing consistency and good quality. On the whole, the basin floor fans exemplify good reservoir quality. The basin floor fans comprise of better petrophysical properties and reservoir quality when compared to slope fan deposits since all petrophysical properties are higher for basin floor fans than slope fans. Moreover, from Fig. 18-22, it is clear that basin floor fans have higher sandstone to basin muds ratio (high net to gross), extensive vertical and lateral bed continuity due to connections between adjoining sandstone bodies when compared to slope fan units; this is distinctly seen in Fig. 22 and 26. The lower petrophysical properties in slope fans when compared to basin floor fans are due to dominant muddy nature.
The 3D model of the Mount Messenger Formation in the Kaimiro-Ngatoro Field specifies the impact of Oligocene network incorporated in this model is shown in Fig. 24. The structure in 3D model (Fig. 24) indicates a broad anticline with four-way dip closure, which was formed in the main phase of movement occurred during the Miocene as a result of widespread compressional tectonics. This phase of deformation was followed by a compressional episode; this is verified by the occurrence of normal faults explained in the earlier sections. The crest of anticline is bisected by a major fault (Inglewood fault) shown in Fig. 24. The 3D model indicates a general westward tilting of the Mount Messenger to recent tectonic activity, the interpreted surfaces and fault 


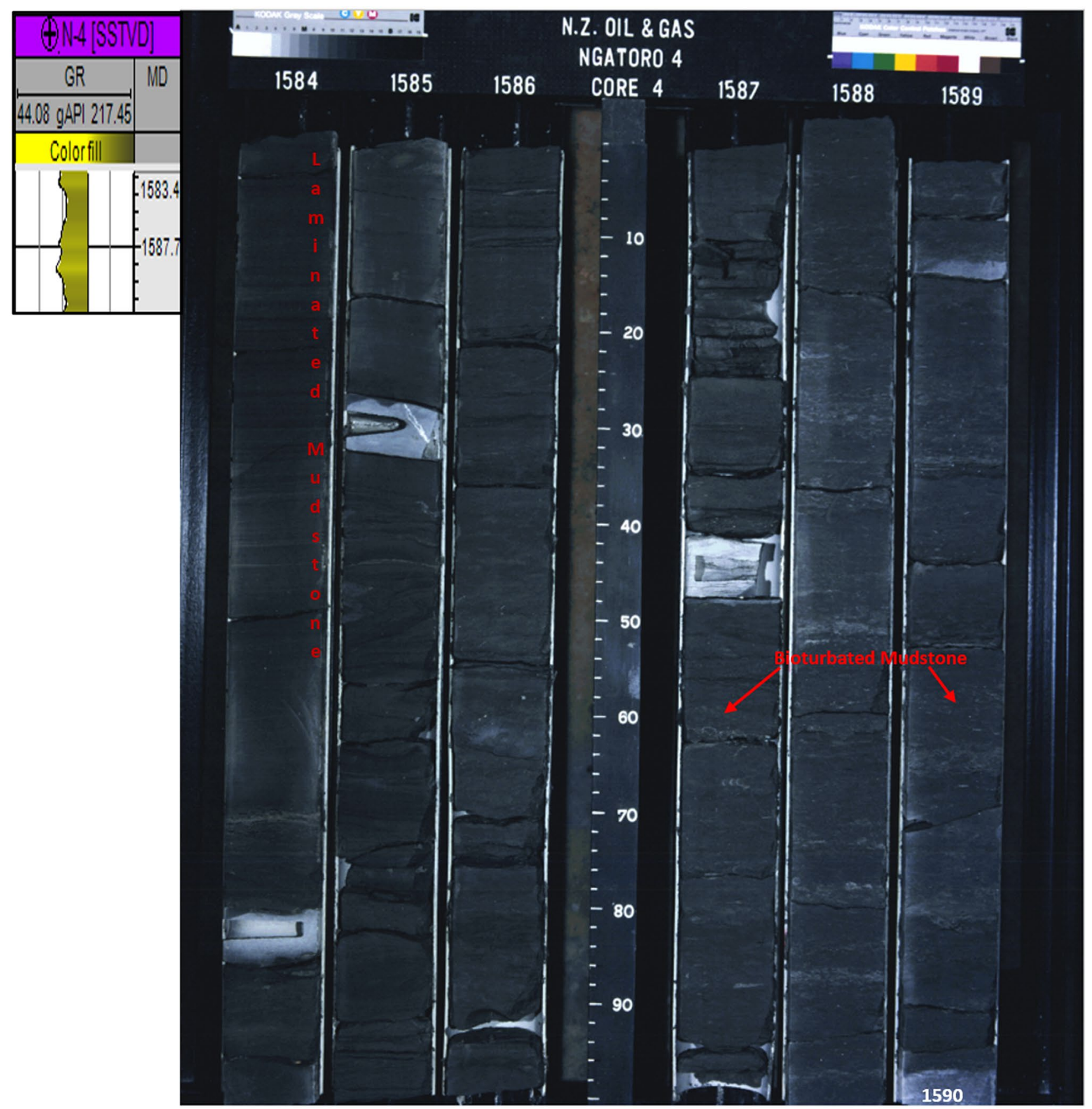

Fig. 21 A core photograph under white light showing example of mudstones (of Bouma subdivision Te) from interval 1584-1590 m of well Ngatoro-4 (N-4), and the low gamma ray value represents hemipelagic/pelagic mudstones

Formation. This observation is matched with King et al. (1993), King and Thrasher (1996) and Vonk et al. (2008), where they inferred that the crust underlying the central North Island lifted during the early Miocene uplift of the eastern and southeastern hinterlands, resulting in tilting of the eastern and southeastern Taranaki Basin strata toward the west direction. Therefore, the 3D structural model of the Mount Messenger Formation in the Kaimiro-Ngatoro
Field with the interpreted surfaces and fault network correlates perfectly with the regional structural dynamics reported by King and Thrasher (1996) and Kroeger et al. (2013) who inferred that volcanism and generated heat of the crust underlying the central North Island during the Pliocene period resulted in uplift of the eastern Taranaki Basin margin and westward tilting. This is in complete agreement 


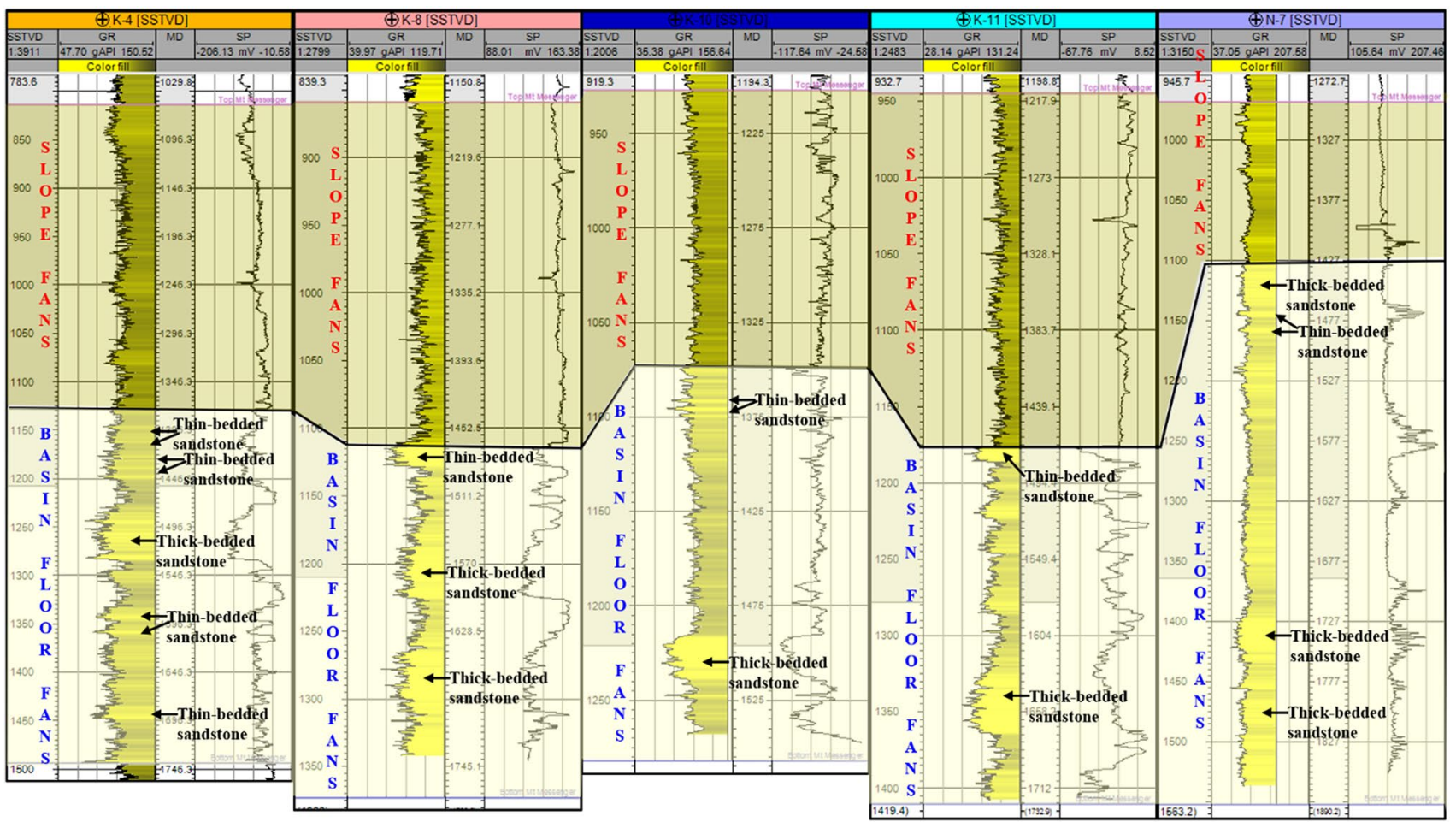

Fig. 22 Gamma ray and SP log character and correlation of stratigraphic units (two stratigraphic intervals are identified) of Mount Messenger Formation within Kaimiro-Ngatoro Field

with the 3D model of Mount Messenger Formation shown in Fig. 24.

\section{Facies modeling}

Facies $\log$ s were interpreted using available core data from wells such as core description, core photographs and their gamma ray (GR) log response; Fig. 15a, b shows the core description and its gamma ray log characteristics of Ngatoro-2 well from depths 1453-1459.96 m and $1548-1554.91 \mathrm{~m}$, respectively. In addition to core description and GR log response of Ngatoro-2 well core photographs were included from depths 1572.77-1591.16 m shown in Fig. 15c. Lithology logs were upscaled based on cored sections data and interpreted un-cored sections of all the wells. Then, the facies model of Mount Messenger Formation (Fig. 27a) was created using sequential indicator simulation (SIS) algorithm and model comprises of five lithologies; the extracted cross section of the model can be seen in Fig. 28a. Among all the lithologies, claystone has highest proportion $(50.57 \%$ ) within formation since the depositional environment is deep-water turbidites, the second majority and important lithology for hydrocarbon storage of the formation is sandstone with proportion of $21.14 \%$, the remaining lithologies of the Mount Messenger Formation are sandy siltstone, mudstone and siltstone with proportions of $9.2 \%, 7.56 \%$ and $11.53 \%$, respectively (Fig. 25). The sandstone beds of the Mount Messenger Formation are very fine in grain size and well sorted (Radwan et al. 2021).

The constructed facies model in Fig. 22a shows the complexity of the lithology distribution laterally and vertically. The model comprises of very thin sand beds minimum sand body of $0.02 \mathrm{~m}$ and thick sand beds greater than $1 \mathrm{~m}$. This can be supported in Fig. 15c, and this figure also indicates that sandstone and siltstone are highly interbedded due to depositional environment of submarine fans. Browne et al. (2005) explained that submarine fans of Mount Messenger Formation consist both basin floor fan and slope fan units having different depositional importance in many aspects. Basin floor fans are from lower part of the formation, and slope fans are comprising upper part of the formation. Basin floor fans are mostly thicker than slope fan units, but often both fan units consist of thin beds. This correlates with the lithofacies model (Fig. 26) where thick sand bodies are existed at the lower part and thinner sand bodies at upper section. As these sand bodies are well sorted with adequate thickness, the Mount Messenger Formation deserves suitable hydrocarbon reservoir units. 

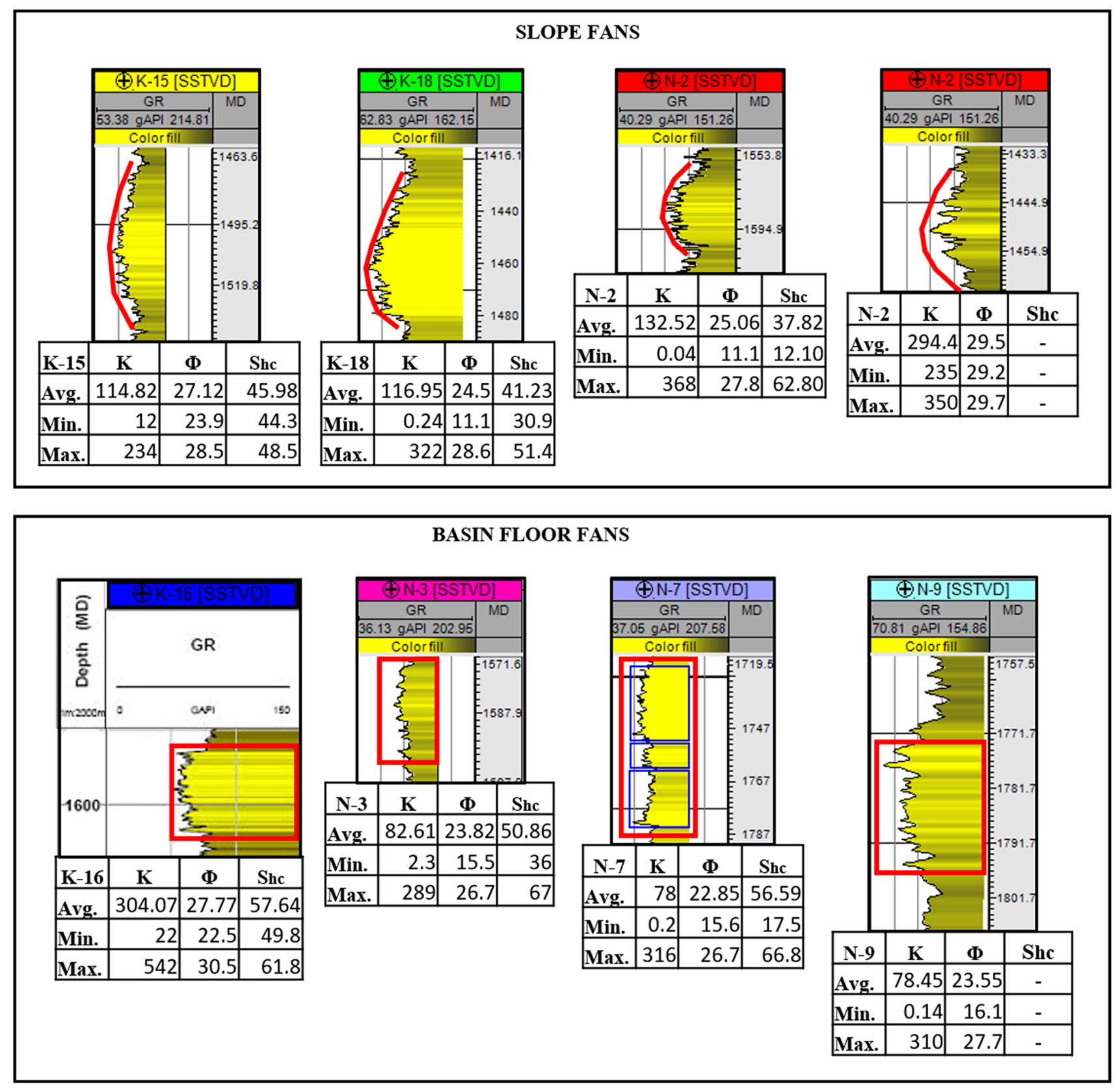

Fig. 23 Depositional environments and their most important petrophysical properties of the Mount Messenger Formation. Permeability is measured as $\mathrm{mD}$, whereas porosity and hydrocarbon saturation in percentage

\section{Petrophysical modeling}

Petrophysical properties were calculated using Interactive Petrophysics (IP) software with the availability of gamma ray, neutron, density and resistivity logs, and the output is shown in Table 5. The properties are porosity (application of neutron-density), water saturation (Indonesian method was applied), net to gross and volume of shale. Since the Mount Messenger Formation is very heterogeneous, instead of applying equations or formulas to calculate permeability, routine core analysis data were utilized to make permeability logs. At first permeability versus depth was plotted on a graph paper, and then, by using Neuralog software it is converted into LAS files and finally imported to Petrel software. Porosity, water saturation, net to gross and volume of shale logs were upscaled by employing "arithmetic method," whereas "harmonic method" was used to upscale permeability log. Then all petrophysical models were generated by utilizing sequential Gaussian simulation (SGS) algorithm incorporating relevant facies from facies model. 


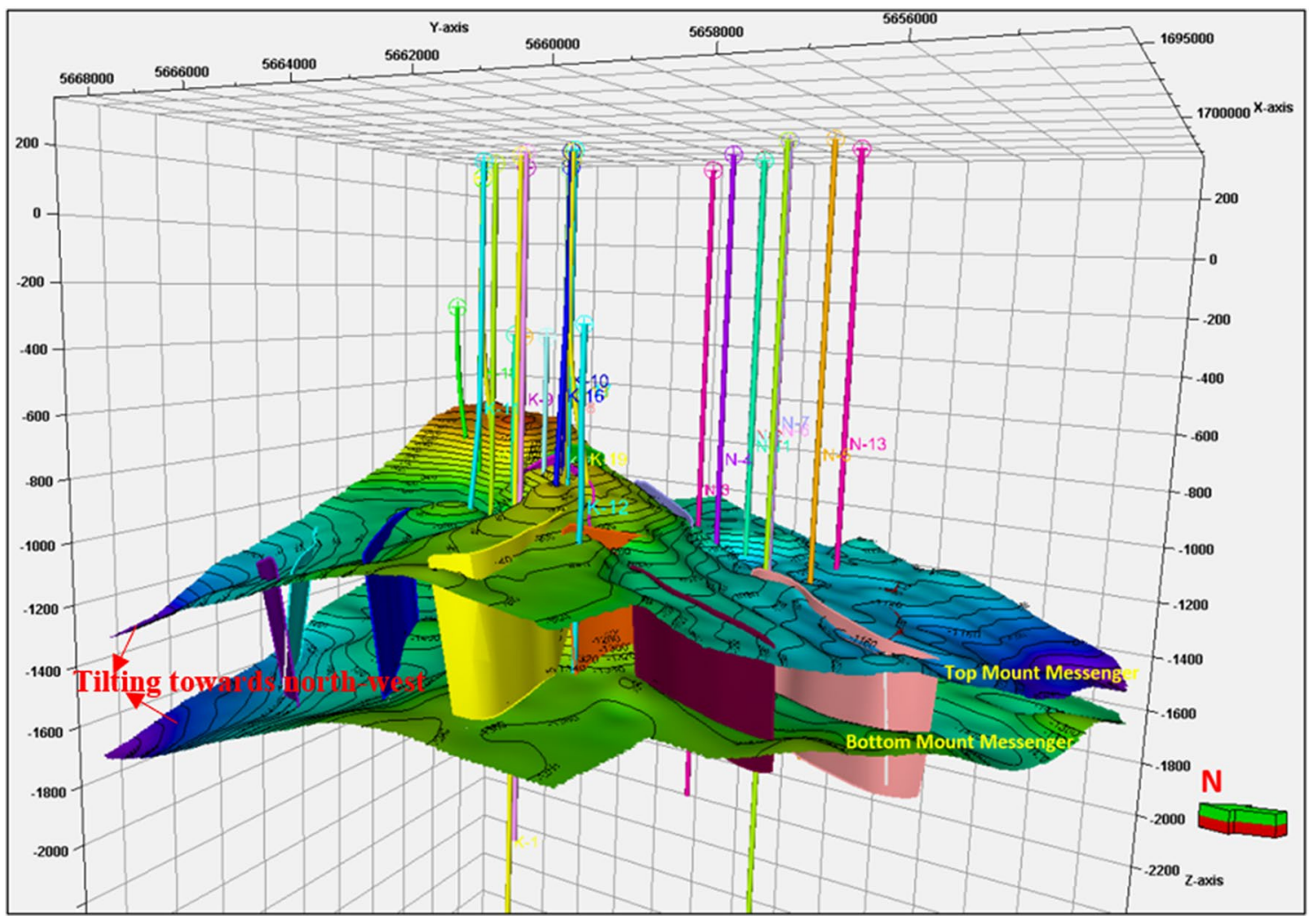

Fig. 24 Distribution of interpreted faults and horizons of Mount Messenger Formation, Kaimiro-Ngatoro Field in 3D model from structural framework
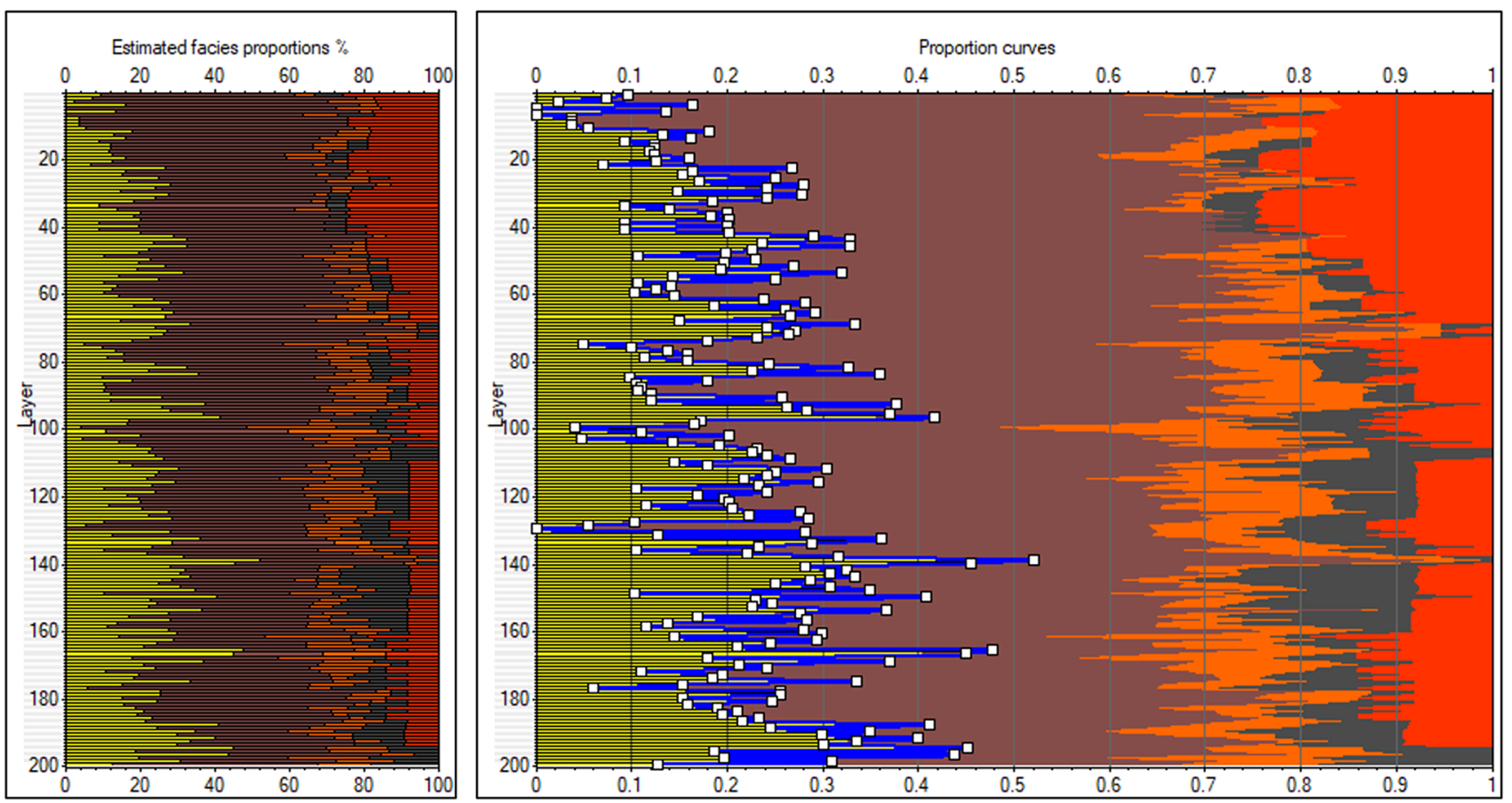

Fig. 25 Facies proportion is analyzed from "data analysis" process, color legends are same as of facies model 

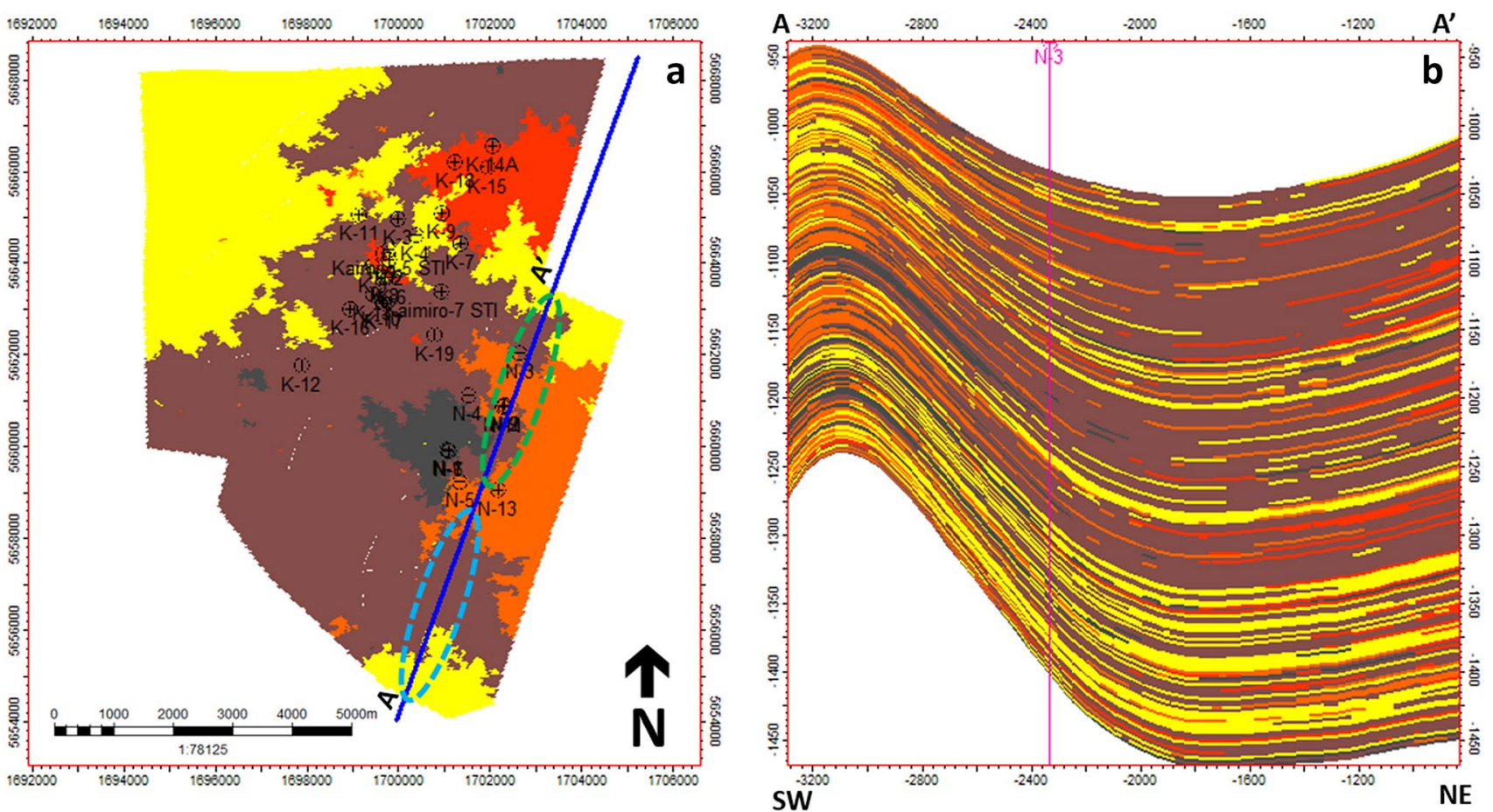

Fig. 26 Facies model a map view b intersection view of cross-sectional A-A' highlighted in green color. Explains that lower part of Mount Messenger Formation consists with basin fan units thicker than slope fan units from upper part of the section

Table 5 Quantitative outputs of the petrophysical parameters (average values) derived from the well log analysis of the Mount Messenger Formation in the Kaimiro-Ngatoro Field. Top and bottom values are in measured depth

\begin{tabular}{lllllclllll}
\hline Well name & Top $(\mathrm{m})$ & Bottom $(\mathrm{m})$ & Gross $(\mathrm{m})$ & Net reservoir $(\mathrm{m})$ & Net pay $(\mathrm{m})$ & $\mathrm{N} / \mathrm{G}(\%)$ & $\mathrm{V}_{\mathrm{sh}}(\%)$ & $\Phi_{\mathrm{e}}(\%)$ & $\mathrm{S}_{\mathrm{w}}(\%)$ & $\mathrm{S}_{\mathrm{hc}}(\%)$ \\
\hline Kaimiro-3 (K-3) & 1250 & 1770 & 520 & 179.45 & 146.53 & 28.3 & 12 & 21.2 & 46.1 & 53.9 \\
Kaimiro-7 (K-7) & 1207 & 2130 & 923 & 922.48 & 87.63 & 9.5 & 8.8 & 17.3 & 47 & 53 \\
Kaimiro-10(K-10) & 1202 & 1557 & 355 & 182.8 & 6.86 & 2 & 17.1 & 21.2 & 45.9 & 54.1 \\
Kaimiro-12(K-12) & 1335 & 1835 & 500 & 464.13 & 5.33 & 1.1 & 10.7 & 20 & 48.5 & 51.5 \\
Kaimiro-13(K-13) & 1110 & 1604 & 494 & 493.09 & 21.95 & 4.4 & 8.7 & 21.9 & 42.9 & 57.1 \\
Ngatoro-3 (N-3) & 1294 & 1687 & 393 & 307 & 18.52 & 4.7 & 11.3 & 22.5 & 48.2 & 51.8 \\
Ngatoro-9 (N-9) & 1463.2 & 2003.9 & 540.7 & 474.8 & 36.42 & 6.8 & 31.4 & 21 & 47.4 & 52.6 \\
Ngatoro-11(N-11) & 1510.2 & 2061.4 & 551.2 & 499.34 & 136.7 & 24.8 & 11.1 & 18.2 & 48 & 52 \\
\hline
\end{tabular}

The effective porosity model (Fig. 27b) shows the spatial distribution within the Mount Messenger Formation, which ranges from 5 to $27.5 \%$. The highly porous zones are exhibited throughout the $3 \mathrm{D}$ model as green, yellow and orange color. The model mostly consists of $20 \%$ porosity, which explains that Mount Messenger Formation contains very good storage capacity and good reservoir quality. Figure $27 \mathrm{c}$ shows permeability distribution throughout the $3 \mathrm{D}$ model of Mount Messenger Formation, which ranges 0.01 to about $600 \mathrm{mD}$. The higher permeable zones can be seen mainly in the sand bodies of the formation. Most of the permeable zones have $200-300 \mathrm{mD}$ permeability. This clearly explains that the reservoir has very good flowing capacity of hydrocarbons and therefore the reservoir quality of the Mount Messenger Formation is very good. The extracted cross-sectional view of porosity and permeability model is shown in Fig. 28b, c.

The volume of shale model (Fig. 27d) shows that Mount Messenger Formation consists of shale ranging up to $70 \%$, most of the zones in the formation comprises of $10-15 \%$ of shale, and the extracted cross-sectional view can be seen in Fig. 28d. The net to gross model (Fig. 27e) comprises of values ranging from 0 to 1 , and this model upholds the 3D effective porosity model, which can be supported by comparing the extracted cross sections of porosity model and net to gross model (Fig. 28b, e). Figure 27f shows the 
Fig. 27 3D view of a facies model, $\mathbf{b}$ porosity model, $\mathbf{c}$ permeability model, $\mathbf{d}$ volume of shale model, e net to gross model, $\mathbf{f}$ water saturation model, g hydrocarbon saturation model, $\mathbf{h}$ reservoir quality index model, i flow zone indicator model of Mount Messenger Formation in Kaimiro-Ngatoro Field
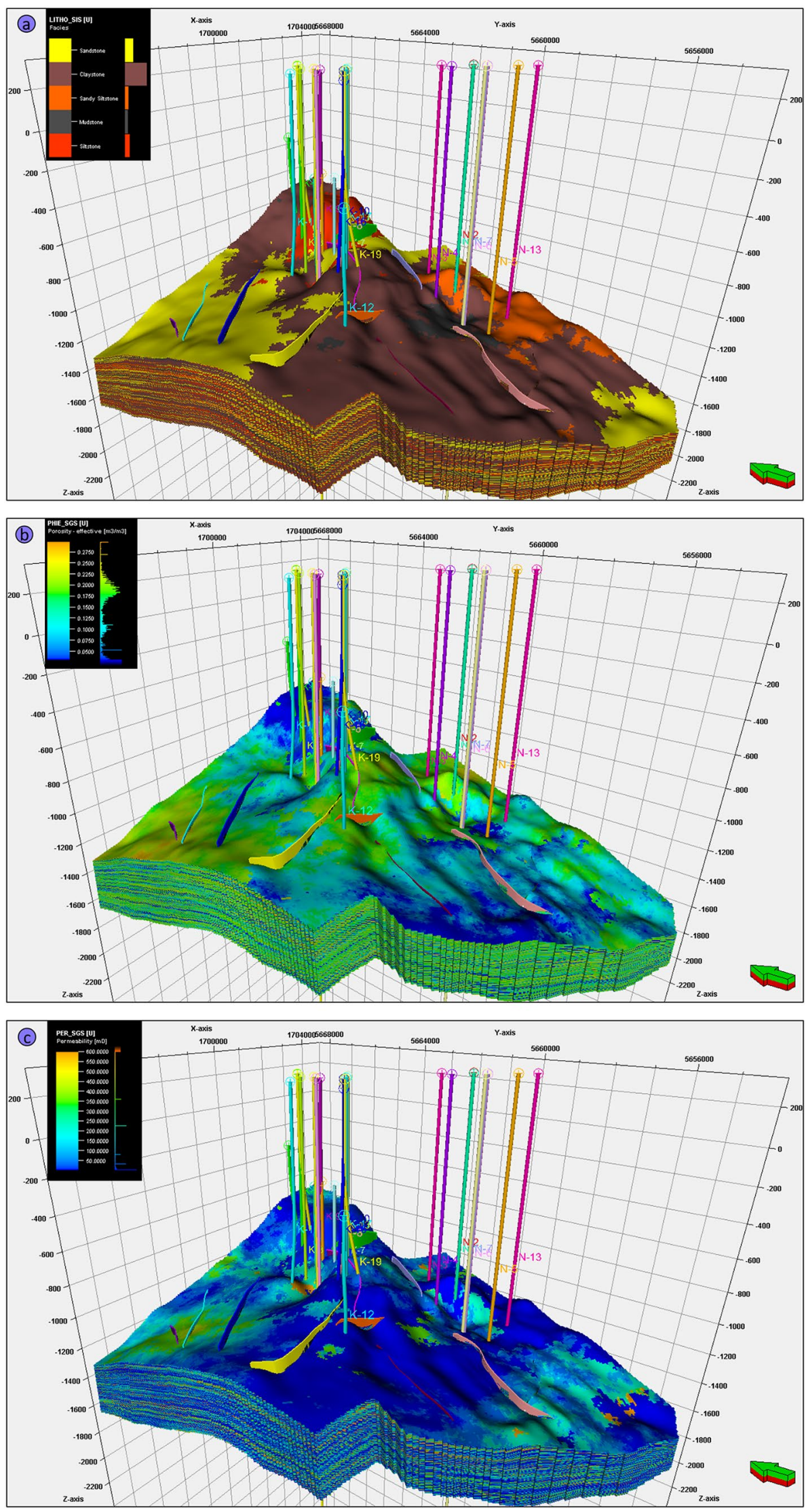
Fig. 27 (continued)
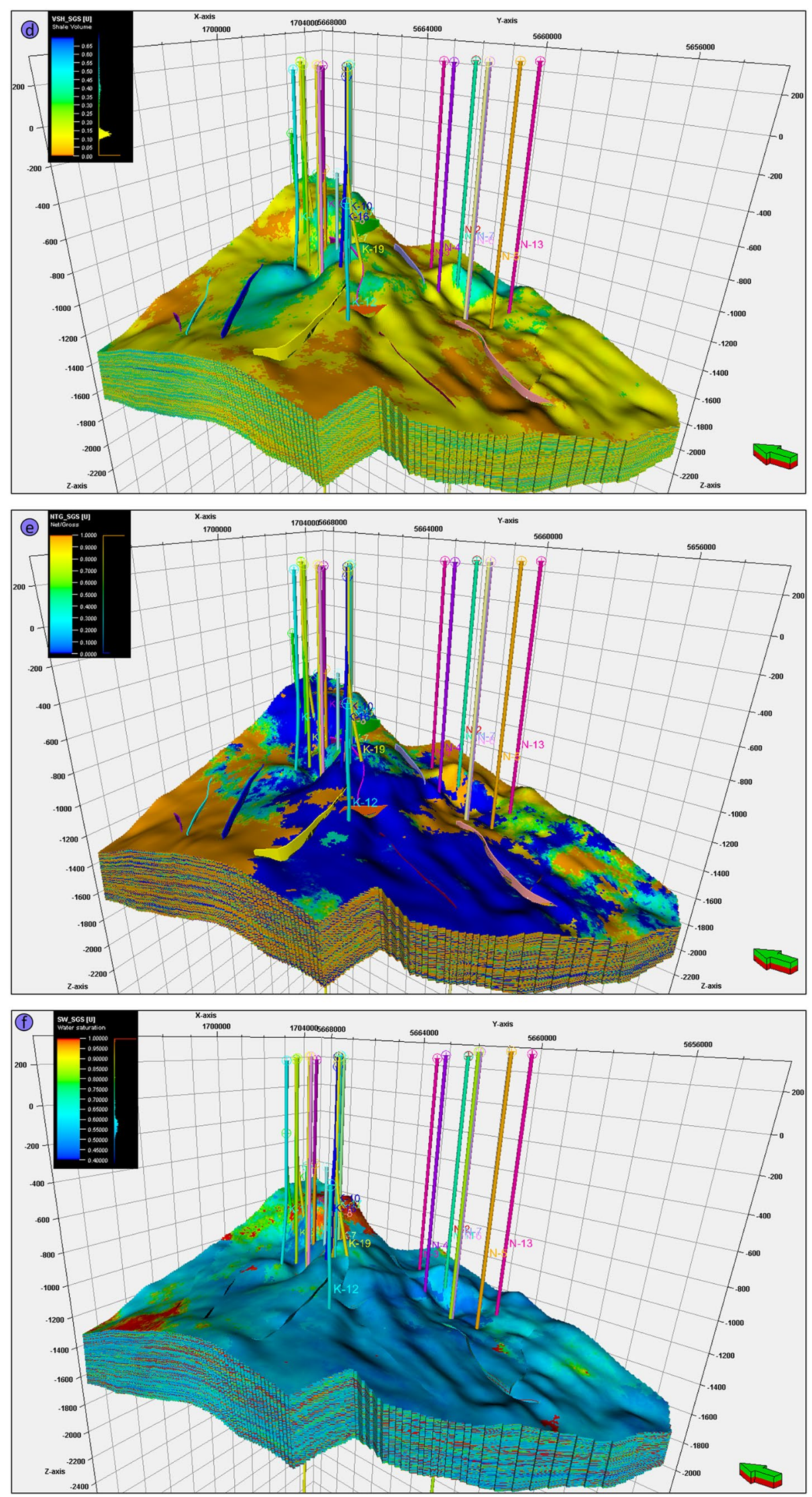
Fig. 27 (continued)
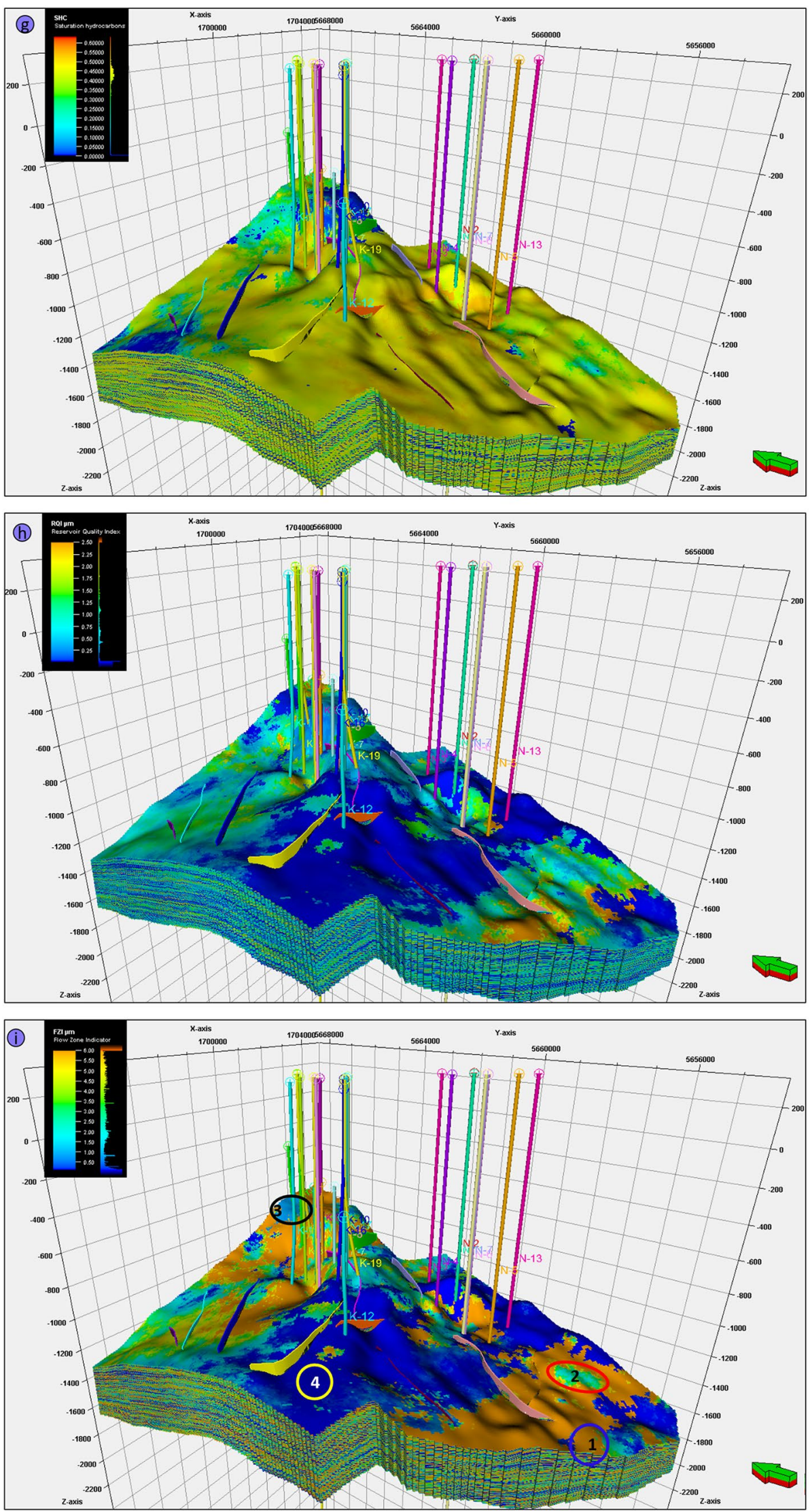


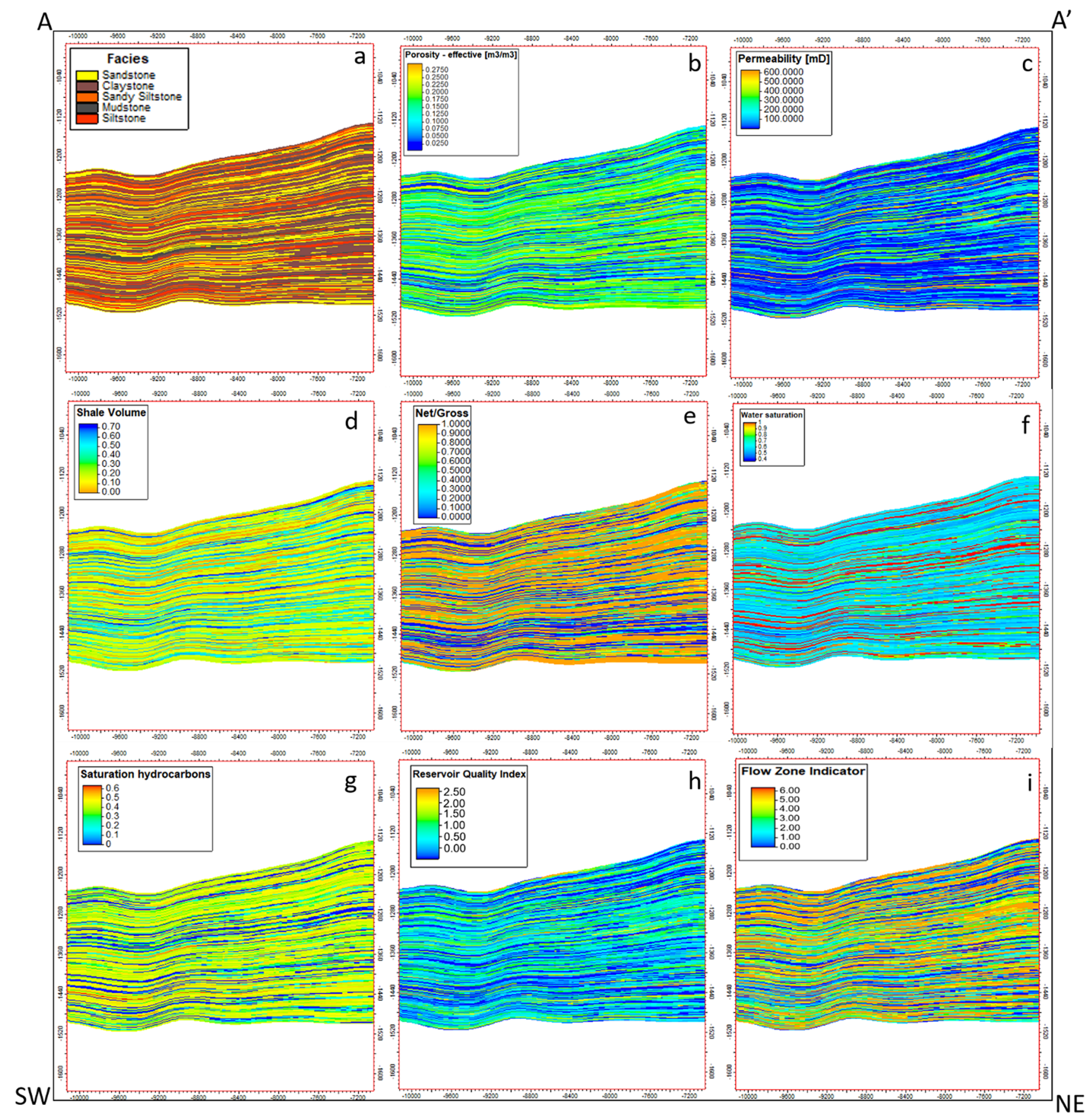

Fig. 28 Extracted cross-sectional A-A' taken from Fig. 26 highlighted in blues color a from lithofacies model, $\mathbf{b}$ to $\mathbf{i}$ from petrophysical model. a Facies. b Porosity. c Permeability. d Volume of shale. e

water saturation distribution throughout the Mount Messenger Formation. This also helps to identify the presence of hydrocarbon in the formation and hydrocarbon saturation model (Fig. 27g) was generated by using Eq. 7. The water saturation model exhibits values ranging from 37 to $100 \%$, whereas the hydrocarbon saturation model consists of values ranging from 0 to $63 \%$. Generally, in the Taranaki Basin,
Net to gross. f Water saturation. g Hydrocarbon saturation. h Reservoir quality index. i Flow zone indicator

many reservoirs were considered $70 \%$ cutoff for water saturation; even Mount Messenger Formation was considered as the same (Radwan et al. 2021). For Mount Messenger Formation hydrocarbon saturation was considered above $50 \%$; therefore, the reservoir quality is good. The extracted cross-sectional views of water saturation and hydrocarbon saturation model are shown in Fig. 28f, g. 


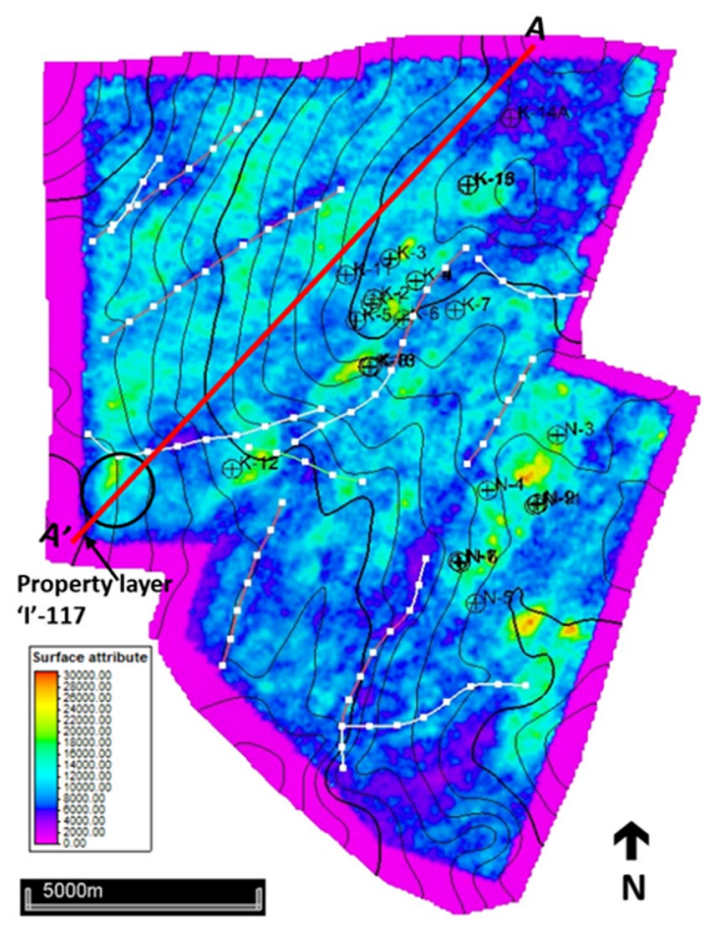

Fig. 29 RMS amplitude seismic attribute map shows proposed area circled in black for future drilling purpose (with cross section of property layer "I"

Figure $27 \mathrm{~h}$ shows the reservoir quality index (RQI) model of Mount Messenger Formation constructed by using Eq. 9, which comprises of values ranging from 0 to above $2.5 \mu \mathrm{m}$. According to Leal et al. (2015), if RQI is greater than $1.8 \mu \mathrm{m}$, then the pores are considered to be megapores and shown by yellow and orange color in the model. If the RQI value is between 0.8 and $1.8 \mu \mathrm{m}$, then the rock consists of macropores and represents greenish areas of the formation in the model. If the RQI is between 0.3 and $0.8 \mu \mathrm{m}$, it indicates the mesopores of the rock and is displayed in light blue color in the model. The micropores have $0.12-0.3 \mu \mathrm{m}$ RQI value and less than $0.12 \mu \mathrm{m}$; RQI represents nanopores of the rock; in RQI model micro- and nanopores are represented by dark blue color. The model indicates that it consists of megapores in some areas, but most of the zones consist of macropores; this explains the potential of the reservoir. The flow zone indicator model (Fig. 27i) was created using Eq. 10, representing four hydraulic flow units. The highest (1) flow units around $6 \mu \mathrm{m}$ can be seen in orange color, the second (2) flow units have FZI value of around $3 \mu \mathrm{m}$ represented by turquoise color, following flow units (3) have FZI value of about $1-1.5 \mu \mathrm{m}$ shown in light blue color, and the lowest (4) hydraulic flow units have FZI value of around $0.5 \mu \mathrm{m}$ and represented in dark blue color. The model indicates that the formation consists mainly of hydraulic flow unit ' 2 ' and unit ' 4 ,' but also some areas are covered by highest flow units. The extracted cross-sectional views of RQI an FZI are shown in Figs. 28h, i.

\section{Implication of 3D modeling on field development}

In this study the developed 3D structural and property models will help to investigate the undrained areas of the Mount Messenger Formation in the Kaimiro-Ngatoro Field along with the examination of spatial distribution of structural and petrophysical attributes. One potential area (Fig. 29) has been identified based on the root-mean-square (RMS) amplitude seismic attribute which shows sign of strong amplitude and also by investigating all the property modeling parameters (Fig. 30) of the area of interest. Figure 30a indicates clearly that most of the sand bodies were sealed by clay due to juxtaposition created by the fault, which means there is compartment in the study area. MM110 (generally between 1000 and $1100 \mathrm{~m}$ TVSS in that area, assuming based on the data available by nearest well, kaimiro-12) and MM70 (around 1200mTVSS) zones are available. According to Fig. 5, the thickness of the Mount Messenger Formation in this area is approx. $400 \mathrm{~m}$, based on this thickness and number of layering incorporated, the thickness of total beds was calculated, in this area the maximum sand body of $10 \mathrm{~m}$ and minimum of $2 \mathrm{~m}$ are exhibited. All petrophysical properties are validating each other in terms of reservoir quality and potential. The petrophysical parameters of the proposed area of further development comprise of 20-25\% porosity, $200-400 \mathrm{mD}$ permeability, around $50 \%$ water saturation and $50 \%$ hydrocarbon saturation, almost $100 \%$ net to gross, having macro- and mesopores and identified as hydraulic flow units of types 1 and 2. Further development of this potential area is expected to increase the production from the Mount Messenger Formation in the Kaimiro-Ngatoro Field if there is further drilling campaign.

\section{Conclusions}

A complete dataset of 3D Kaimiro-Ngatoro Field including seismic data, core data and well data was used to understand and assess the structure, stratigraphy, petrophysical properties and reservoir characterization of the Mount Messenger Formation. Five lithofacies that is sandstone, sandy siltstone, siltstone, claystone and mudstone are identified with intensive bioturbation, horizontal lamination and ripple/climbing ripple lamination sedimentary structures (Bouma sequence divisions), but a complete Bouma sequence is not observed. The gamma ray and SP logs helped to divide Mount Messenger into two stratigraphic units: basin floor fans which shows blocky $\log$ motif and slope fans which are represented by crescent or bell-shaped log motif. Basin floor fans comprise of thick-bedded and thin-bedded sandstones, whereas slope 
A
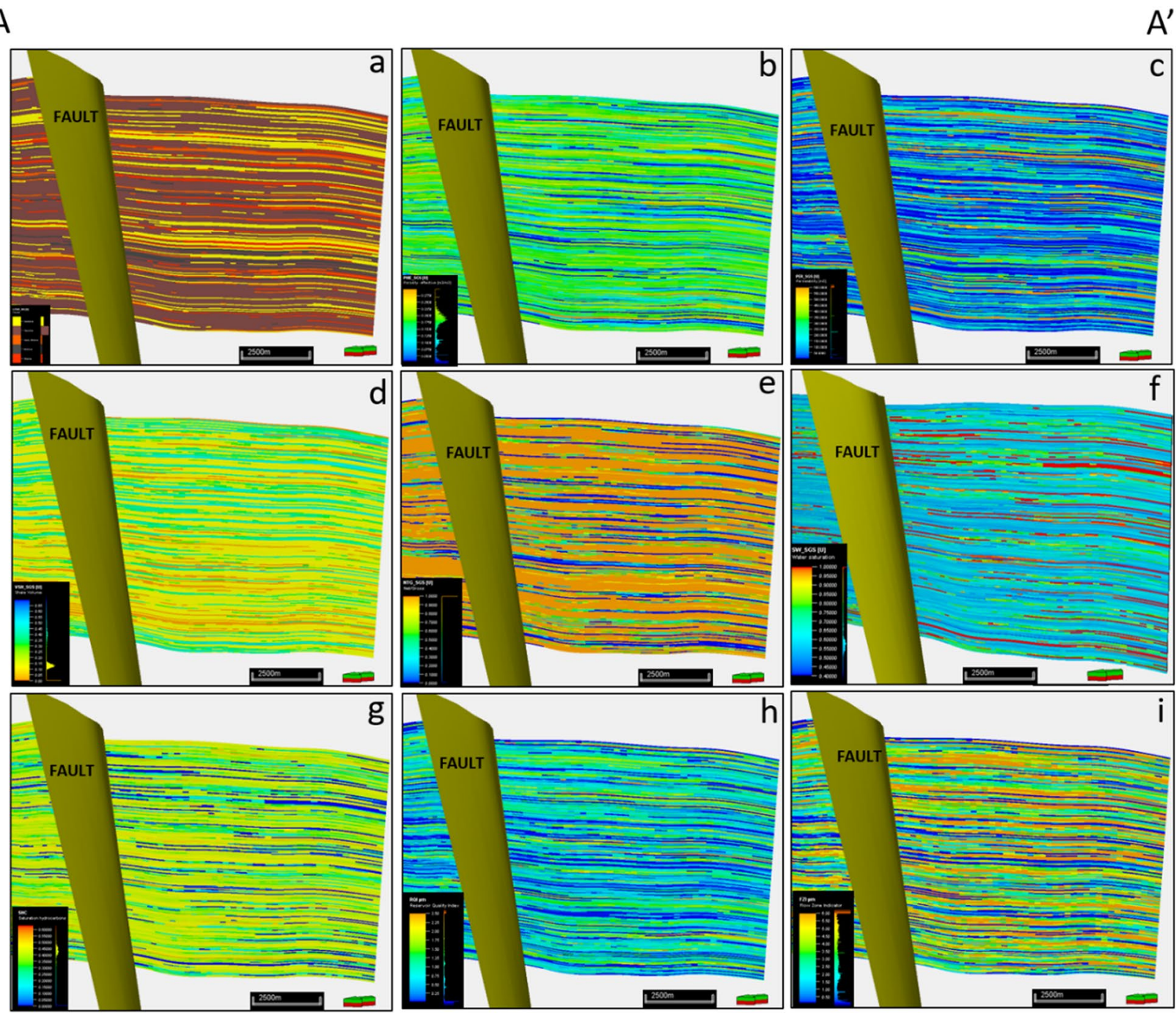

SW
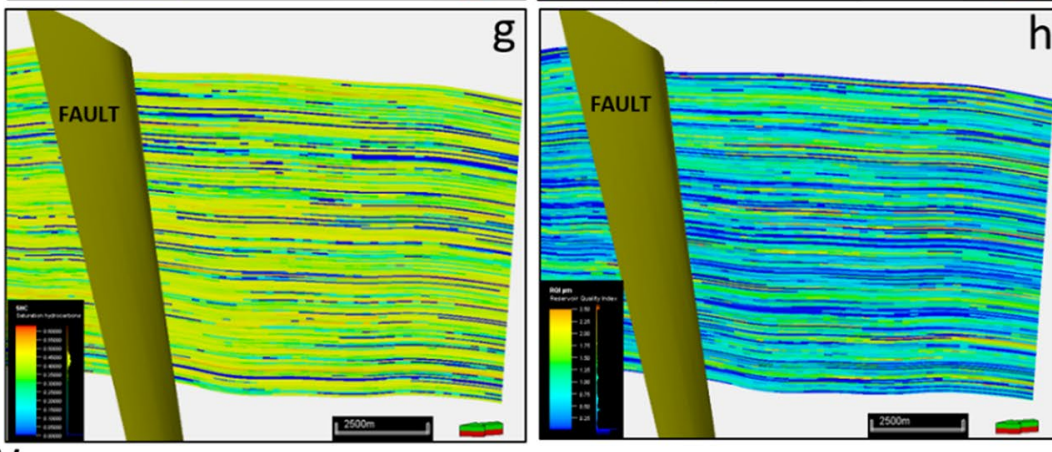

Fig. 30 Property modeling and petrophysical modeling view of property layer "I"-117 of the model, which exhibits good reservoir properties a Facies. b Porosity. c Permeability. d Volume of shale. e Net to

fans consist of sandy intervals (sandstone interbedded with basin muds). In comparison with slope fans, basin floor fans possess better reservoir quality with higher petrophysical properties, where porosity values range from 15.5 to $30.5 \%$, permeability value varying from 0.14 to $542 \mathrm{mD}$ and hydrocarbon saturation ranges $61.8-67 \%$. The structural model was generated by using volume-based modeling algorithm with an input of interpreted 2 horizons and 11 faults. Major fault, the Inglewood fault set apart the Kaimiro Field and Ngatoro Field. Most of the faults have throw less than $10 \mathrm{~m}$, and most of the faults have high dip angles of $70-80^{\circ}$. The constructed 3D property models assist to study spatial distribution of lithofacies and petrophysical parameters. The petrophysical parameters comprise of porosity values ranging from 5 to $27.5 \%$, permeability values are up to $600 \mathrm{mD}$, gross. f Water saturation. g Hydrocarbon saturation. h Reservoir quality index. i Flow zone indicator

minimum value of water saturation is $37 \%$, and maximum value of hydrocarbon saturation is $63 \%$ with four hydraulic units and most of macropores in nature. The detailed examination of 3D reservoir modeling in this study determines that very fine, well-sorted Mount Messenger Formation has very good reservoir quality. The proposed area for future drilling has been identified based on the examination of 3D property modeling if there is any future development plan. This study can be equally treated as an example of modeling the deepwater turbidites with similar setting elsewhere in the world.

Acknowledgements Authors would like to thank Ministry of Business, Innovation and Employment (MBIE), New Zealand, for providing dataset containing 3D seismic, well logs and well completion reports required for this study. This study has been funded as part of the doctoral research undertaken at the Department of Geosciences, Universiti

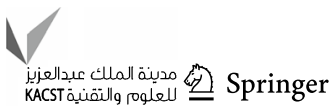


Brunei Darussalam (UBD), in the form of UBD Graduate Scholarship (UGS). Authors are grateful to the Department of Geosciences, UBD, for providing workstation facilities and thankful to Phua Eng Siong for his logistic supports. Schlumberger is greatly acknowledged for supporting us with Petrel software v.2019.

Funding The first author got funding for this $(\mathrm{PhD})$ study in the form of University Graduate Research scholarship.

\section{Declarations}

Conflict of interest The authors declare that there is no conflict of interest. Authors would like to confirm that this work is authors' own original work which has not been published previously and that it is not under consideration for publication elsewhere. This paper reflects the authors' own research and analysis in a truthful and complete manner. Plagiarism has been checked for this manuscript, and it is below the acceptable percentage. This paper properly credits the meaningful contributions of co-authors. Authors would like to confirm that all authors have been personally and actively involved in substantial work leading to the paper, and all sources used are properly disclosed.

Open Access This article is licensed under a Creative Commons Attribution 4.0 International License, which permits use, sharing, adaptation, distribution and reproduction in any medium or format, as long as you give appropriate credit to the original author(s) and the source, provide a link to the Creative Commons licence, and indicate if changes were made. The images or other third party material in this article are included in the article's Creative Commons licence, unless indicated otherwise in a credit line to the material. If material is not included in the article's Creative Commons licence and your intended use is not permitted by statutory regulation or exceeds the permitted use, you will need to obtain permission directly from the copyright holder. To view a copy of this licence, visit http://creativecommons.org/licenses/by/4.0/.

\section{References}

Abul Khair H, Cooke D, Backé G, King R, Hand M, Tingay M, Holford S (2012). Subsurface mapping of natural fracture networks; a major challenge to be solved. Case study from the shale intervals in the Cooper Basin, South Australia. In: workshop on geothermal reservoir engineering (37th: 2012: Stanford, California)

Adelu AO, Aderemi AA, Akanij AO, Sanuaded OA, Kakad SI, Afolabi A et al (2019) Application of 3D static modeling for optimal reservoir characterization. J Afr Earth Sci 152:184-196

AlHakeem A (2018). 3D seismic attribute analysis and machine learning for reservoir characterization in Taranaki Basin, New Zealand. Doctoral Dissertation 2659. Missouri University of Science and Technology

Alotaby WD (2015). Fault interpretation and reservoir characterization of the farewell formation within Kerry field, Taranaki Basin, New Zealand. Masters Theses 7458. Missouri University of Science and Technology

Alotaibi MDM (2015) Seismic structural investigation and reservoir characterization of the Moki Formation in Maar Field, Taranaki Basin, New Zealand. Masters Theses. 7459. https://scholarsmine. mst.edu/masters theses/7459

Amaefule JO, Altunbay M, Tiab Kersey Keelan (1993). Enhanced reservoir description: using core and log data to identify hydraulic (flow) units and predict permeability in uncored intervals/ wells. In: presented at the SPE annual technical conference and exhibition, Houston, 3-6 October. https://doi.org/10.2118/26436MS. SPE 26436

Dresser A (1979). Log Interpretation Charts. Dresser Industries, Houston, TX. $107 \mathrm{pp}$

Baur J, Sutherland R, Stern T (2014) Anomalous passive subsidence of deep-water sedimentary basins: a pre arc basin example, southern New Caledonia Trough and Taranaki Basin. New Zealand Basin Res 26(2):242-268. https://doi.org/10.1111/bre.12030

Bouma AH, Normark WR, Barnes NE (1985). Submarine Fans and Related Turbidite Systems. Springer-Verlag, p 352

Bouma AH (1962) Sedimentology of Some Flysch Deposits. Amsterdam; New York: Elsevier Pub. Co

Browne GH, Slatt RM (2002) Outcrop and behind-outcrop characterization of a late Miocene slope fan system, Mt. Messenger Formation, New Zealand. The American Association of Petroleum Geologists, 86(5), p 841-862

Browne GH, King PR, Higgs KE, Slatt RM (2005) Grain-size characteristics for distinguishing basin floor fan and slope fan depositional settings: outcrop and subsurface examples from the late Miocene mount messenger formation, New Zealand. New Zealand J Geol Geophys 48:213-227

Cantalejo B, Pickering KT (2014) Climate forcing of fine-grained deepmarine systems in an active tectonic setting: middle Eocene, Ainsa Basin, Spanish Pyrenees. Palaeogeogr Palaeoclimatol Palaeoecol 410:351-371

Crundwell MP (2004b) New Zealand upper Miocene timescale: dating and correlating the Mount Messenger Formation in north Taranaki. In: proceedings of 2004 New Zealand petroleum conference. Ministry of Economic Development, Wellington

Crundwell MP (2004a). New Zealand late Miocene biostratigraphy and biochronology: Studies of planktic foraminifers and bolboforms at oceanic sites 593 and 1123, and selected onland sections. Unpublished $\mathrm{PhD}$ thesis. Earth Sciences Department, University of Waikato, Hamilton, p 678

Dong SP, Shalaby MR, Islam MA (2018) Integrated reservoir characterization study of the McKee Formation, Onshore Taranaki Basin, New Zealand. Geosciences. https://doi.org/10.3390/geosc iences8040105

Flint SS, Hodgson DM, Sprague AR, Brunt RL, Van der Merwe WC, Figueiredo J, Prélat A, Box D, Di Celma C, Kavanagh JP (2011) Depositional architecture and sequence stratigraphy of the Karoo basin floor to shelf edge succession, Laingsburg depocentre, South Africa. Mar Petrol Geol 28:658-674

Franzel M, Back S (2019) Three-dimensional seismic sedimentology and stratigraphic architecture of prograding clinforms, central Taranaki Basin. New Zealand Int J Earth Sci 108(2):475-496. https://doi.org/10.1007/s00531-018-1663-1

Ghosh B, Lowe DR (1993) The Architecture of Deep-Water Channel Complexes. Cretaceous Venado Sandstone Member, Sacramento Valley, California

Graham SA, Bachman SB (1983) Structural controls on submarine fan geometry and internal architecture: upper La Jolla fan system, offshore southern California. Am Assoc Petroleum Geol Bull 67(1):83-96. https://doi.org/10.1306/03B5ACC8-16D1-11D7$8645000102 \mathrm{C} 1865 \mathrm{D}$

Grahame J (2015) Deepwater Taranaki Basin, New Zealand - New Interpretation and Modelling Results for Large Scale Neogene Channel and Fan Systems: Implications for Hydrocarbon Prospectivity, *Adapted from extended abstract prepared in conjunction with oral presentation at AAPG/SEG. In: international conference and exhibition, Melbourne, Australia, September 13-16, 2015, AAPG/SEG 2015

Griffin AG, Bland KJ, Field B, Strogen DP, Crutchley G, Lawrence MJ et al. (2015). Reservoir characterization of East Coast and Pegasus 
Basin, Eastern North Island, New Zealand. In: international conference and exhibition, Melbourne, Australia, 13-16 September 2015, p 150 https://doi.org/10.1190/ice2015-2207834

Hadiloo S, Hashemi H, Mirzaei S, Beiranvand B (2017) SeisART software: seismic facies analysis by contributing interpreter and computer. Arabian J Geosci. https://doi.org/10.1007/ s12517-017-3274-8

Haque AKME, Islam MA, Shalaby MR (2016) Structural modeling of the Maui Gas Field, Taranaki Basin. New Zealand Petroleum Explorat Develop 43(6):883-892. https://doi.org/10.1007/ s11053-020-09744-x

Hashemi H (2012) Fuzzy clustering of Seismic Sequences: Segmentation of Time-Frequency Representations. IEEE Signal Process Mag 29(3):82-87

Kristian H (2003), Anatomy and allostratigraphy of deep-marine Mount Messenger Formation (Miocene), eastern-margin Taranaki Basin, New Zealand. Thesis for partial fulfillment of Candidatus Scientiarum degree in sedimentology/petroleum geology, 2003. https://core.ac.uk/download/pdf/ 30852592.pdf

Higgs KE, King PR, Raine JI, Sykes R, Browne GH, Crouch EM et al (2012) Sequence stratigraphy and controls on reservoir sandstone distribution in an Eocene marginal marine-coastal plain fairway, Taranaki Basin, New Zealand. Mar Pet Geol 32:110-137. https:// doi.org/10.1016/j.marpetgeo.2011.12.001

Higgs KE, King PR, Browne GH, Morgans HEG (2004). Oligocene submarine fan systems in Taranaki: a proven reservoir and an outcrop comparison. In: New Zealand petroleum conference proceedings 2004, 10 pp. Wellington: Ministry of Economic Development

Higgs KE, Crouch EM, Raine JI (2017) An interdisciplinary approach to reservoir characterization: An example from the early to middle Eocene Kaimiro Formation, Taranaki Basin, New Zealand. Mar Pet Geol 86:111-139. https://doi.org/10.1016/j.marpetgeo. 2017.05.018

Holt WE, Stern TA (1994) Subduction, platform subsidence, and foreland thrust loading: The late Tertiary development of Taranaki Basin. New Zealand. Tectonics 13(5):1068-1092. https://doi.org/ 10.1029/94tc00454

Ilg BR, Samuel HS, Nicol A, Baur J, Fohrmann M, Funnell R et al (2012) Normal faults and gas migration in an active plate boundary, southern Taranaki Basin, offshore New Zealand. AAPG Bull 96:1733-1756. https://doi.org/10.1306/02011211088

Infante-Paez L, Marfurt KJ (2017). Seismic expression and geomorphology of igneous bodies: A Taranaki Basin, New Zealand, case study. Interpretation 5, SK121-SK140, https://doi.org/10.1190/ INT-2016-0244.1

Islam MA, Mutiah Y, Qadri SMT, Shalaby MR, Haque AKME (2020), Three-Dimensional Structural and Petrophysical Modeling for Reservoir Characterization of the Mangahewa Formation, Pohokura Gas-Condensate Field, Taranaki Basin, New Zealand. Nat Resourc Res, https://doi.org/10.1007/s11053-020-09744-x

Jumat N, Shalaby MR, Haque AKME, Islam MA, Hoon LL (2018) Geochemical characteristics, depositional environment and hydrocarbon generation modeling of the upper Cretaceous Pakawau Group in Taranaki Basin, New Zealand. J Pet Sci Eng 163:320-339

King, P.R., Browne, G.H., (2001). Miocene Turbidite Reservoir Systems in the Taranaki Basin, New Zealand: Established plays and analogues for deep-water exploration. In: PESA Eastern Australasian Basins symposium proceedings, p 129-139

King PR, Thrasher GP (1996) Cretaceous-cenozoic geology and petroleum systems of the Taranaki Basin, New Zealand. Inst Geol Nucl Sci Monogr 13:244

King PR, Naish TR, Thrasher GP (1991) Structural cross sections and selected palinspastic reconstructions of the Taranki basin, New Zealand. New Zealand Geological Survey Report, 1991, G-150
King PR, Scott GH, Robinson PH (1993). Description, correlation and depositional history of Miocene sediments outcropping along North Taranaki coast: institute of geological and nuclear sciences monograph. 5, 199

King PR, Browne GH, Slatt MR (1994). Sequence Architecture of Exposed Late Miocene Basin Floor Fan and Channel-Levee Complexes (Mount Messenger Formation), Taranaki Basin, New Zealand. In: GCSSEPM foundation 15th annual research conference submarine fans and turbidite systems

Kroeger K, Funnell R, Nicol A, Fohrmann M, Bland K, King P (2013) 3D crustal-scale heat-flow regimes at a developing active margin (Taranaki Basin, New Zealand). Tectonophysics 591:175-193. https://doi.org/10.1016/j.tecto.2012.04.005

Kutovaya A, Kroeger KF, Seebeck H, Back S (2019) Thermal effects of magnetism on surrounding sediments and petroleum systems in the Northern Offshore Taranaki Basin, New Zealand. Geosci. https://doi.org/10.3390/geosciences 9070288

Leal J, Gaibor J, Garces S (2015). New Approaching for Rock Types and Lithofacies Synergy for the Hollin Formation, Palo Azul Field, Ecuador. Society of Petroleum Engineers SPE-177156-MS, 2015

Levorsen AI (1967). Geology of petroleum. WH Freeman, San Fransisco, 350p

Marfurt KJ, Scheet RM, Sharp JA, Harper MG (1998) Suppression of the acquisition footprint for seismic sequence attribute mapping. Geophysics 63(3):1024-1035. https://doi.org/10.1190/1.1444380

Masalimova LU, Lowe DR, Sharman GR, King PR, Malcolm JA (2016) Outcrop characterization of a submarine channel-lobe complex: the lower Mount messenger formation, Taranaki Basin, New Zealand. Mar Pet Geol 71:360-390. https://doi.org/10.1016/j.marpe tgeo.2016.01.004

Mennan A (2017). Well log interpretation and 3D property modeling of Maui-B Field, Taranaki Basin, New Zealand, Master Theses, 7722. Missouri University of Science and Technology. https:// scholarsmine.mst.edu/masters_theses/7722/

Mitchum M, Sangree JB, Vail PR, Wornard WW (1993). Recognizing sequences and systems tracts from well logs, seismic data, and biostratigraphy: examples from the Late Cenozoic of the Gulf of Mexico: chapter 7: recent applications of siliciclastic sequence stratigraphy. In: Weimer, P., Posamentier, H.W. (Eds.), Siliciclastic Sequence Stratigraphy: Recent Developments and Applications. AAPG Tulsa, p 163-197

Nicol A, Stagpoole VM, Maslen G (2004). Structure and petroleum potential of the Taranaki fault play//New Zealand Petroleum Conference, Tenaris, Siderca, Argentina, pages 7-10

Normark WR, Piper DJW (1984) Navy Fan, California Borderland: growth pattern and depositional processes. Geo-Mar Lett 3(24):101-108. https://doi.org/10.1007/BF02462454

Palmer J, Geoff B (1988). Taranaki Basin, New Zealand. Active Margin Basins, p 269-290

Palmer J (1985) Pre-miocene lithostratigraphy of Taranaki Basin, New Zealand. N Z J Geol Geophys. 28(2):197-216. https://doi.org/10. 1080/00288306.1985.10422220

Pilaar WFH, Wakefield LL (1978) Structural and stratigraphic evolution of the Taranaki Basin, offshore North Island. New Zealand. APEA J. 18:93-101. https://doi.org/10.1071/AJ77011

Posamentier HW, Erskine RD (1991) Seismic expression and recognition criteria of ancient submarine fans, In: Weimer P, and MH Link (Eds.), Seismic Facies and Sedimentary Processes of Submarine Fans and Turbidite Systems: Springer-Verlag, New York, p 197-222

Posamentier HW, Vail PR (1988). Eustatic controls on clastic deposition II-sequence and systems tract models, in Wilgus CK, BS Hastings, CG St. C Kendell, HW Posamentier, CA Ross, and JC Van Wagoner, eds., Sea Level Change-An Integrated Approach:

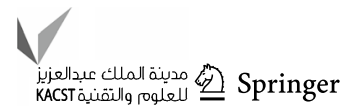


Society of Economic Paleontologists and Mineralogists Special Publication, 42, 125-154

Posamentier HW, Walker RG (2006). Deep-water turbidites and submarine fans: 399-520, doi:https://doi.org/10.2110/pec.06.84.0339

Poupon A, Leveaux J (1971). Evaluation of water saturation in shaly formations. In: proceedings of the SPWLA 12th annual logging symposium

Prieto AM, Archer R (2015). Rock typing in geothermal reservoirs of New Zealand. In: SPWLA 56th annual logging symposium, July 18-22, 2015. SPWLA-2015-RR. https://doi.org/10.13140/RG.2. 1.1.167.5368

Qadri SMT, Shalaby MR, Islam MA, Hoon LL (2016) Source Rock Characterization and hydrocarbon generation structural of the middle to Late Eocene Mangahewa Formation in Taranaki Basin. New Zealand. Arabian J Geosci 9:559

Qadri SMT, Islam MA, Shalaby MR, Haque AKME (2017) Seismic interpretation and structural modelling of Kupe Field, Taranaki Basin. New Zealand. Arabian J Geosci 10:295

Qadri SMT, Islam MA, Shalaby MR (2019) Three Dimensional petrophysical structural and volumetric analysis to model the reservoir potential of the Kupe Field, Taranaki Basin, New Zealand. Nat Resourc Res 28:369-392

Radwan AA, Nabawy BS, Abdelmaksoud A, Lashin A (2021) Integrated sedimentological and petrophysical characterization for clastic reservoirs: a case study from New Zealand. J Nat Gas Sci Eng. https://doi.org/10.1016/j.jngse.2021.103797

Roncaglia L, Arnot M, Baur J, Forhmann M, King P, Kroeger KF, et al. (2010) Integrated workflow for modeling basin-scale petroleum systems: applications to the Kupe Area, Taranaki, New Zealand. SPE. https://doi.org/10.2118/133903-MS

Roncaglia L, Forhmann M, Milner M, Morgans HEG, Crundwell MP (2013). Well log stratigraphy in the central and southern offshore area of the Taranaki Basin, New Zealand. GNS Sciences Report, 2013/27, 26p + enclosures

Rotzein JR, Lowe DR, King PR, Browne GH (2014) Stratigraphic architecture and evolution of a deep-water slope channel-levee and overbank apron: the upper miocene upper mount messenger formation, Taranaki Basin. Mar Pet Geol 52:22-41

Sarma M, Kellet R, Pryde S, Reynolds G (2014). Petroleum systems structural: Charge evaluation of the Eltham area (PEP 51150) (p 6). Wellington: Onshore Taranaki Basin: New Zealand Corp

Schlumberger (1989) Cased hole log interpretation principles/applications. Sugar Land, Texas, Schlumberger Educational Services, $198 \mathrm{p}$
Schlumberger (1991). Log interpretation principles/applications. Sugar Land, Texas, Schlumberger Educational Services, 226

Schofield JC (1959). Mohakatino Formation (Series): Mid-Upper Miocene (North Taranaki). In: Fleming, C.S. ed. Lexique stratigraphique international, Paris, France. Centre National de la Recherche Scientifique, 6(4), 238

Shanmugam G (2016) Submarine fans: a critical retrospective (19502015). J Palaeogeograp 5(2):110-184

Silver C, Bedle H (2021) Evolution of a late Miocene deep-water depositional system in the Southern Taranaki Basin. New Zealand Gesci. https://doi.org/10.3390/geosciences11080329

Stagpoole V, Nicol A (2008) Regional structure and kinematic history of a large subduction back thrust; Taranaki Fault New Zealand. J Geophys Res 113:B01403

Strogen DP, Bland KJ, Nicol A, King PR (2014) Paleogeography of the Taranaki Basin region during the latest Eocene-Early Miocene and implications for the 'total drowning' of Zealandia. New Zealand J Geol Geophys 57(2):110-127

Sykes SH (2012) The Influence of Faulting on Hydrocarbon Migration in the Kupe Area, South Taranaki Basin, New Zealand. Thesis for partial fulfillment for the degree of Masters of Science in Petroleum Geoscience. School of Geography, Environment and Earth Sciences Victoria University of Wellington, $211 \mathrm{p}$

Thrasher G.P (1992) Late Cretaceous geology of Taranaki Basin, New Zealand, Unpublished PhD thesis, Victoria University of Wellington

Uruski CI (2008) Deepwater Taranaki, New Zealand structural development and petroleum potential. Explor Geophys 39(2):94-107. https://doi.org/10.1071/EG08013

Vonk AJ, Kamp PJJ (2008). The Late Miocene Southern and Central Taranaki Inversion Phase (SCTIP) and related sequence stratigraphy and paleogeography. In: proceedings of the 2008 New Zealand petroleum conference, Auckland, New Zealand, 9-12 March 2008

Weimer P, Link MH (1991) Global petroleum occurrences in submarine fans and turbidite systems. In: Weimer P, Link MH (eds) Seismic facies and sedimentary processes of submarine fans and turbidite systems. Springer-Verlag, New York, pp 9-67

Worthington PF (2010) Net pay-what is it? what does it do? how do we quantify? How do we use it? SPE Reservoir Eval Eng 13(5):812-822

Publisher's Note Springer Nature remains neutral with regard to jurisdictional claims in published maps and institutional affiliations. 